\title{
The SURFEXv7.2 land and ocean surface platform for coupled or offline simulation of earth surface variables and fluxes
}

\author{
V. Masson ${ }^{1}$, P. Le Moigne ${ }^{1}$, E. Martin $^{1}$, S. Faroux ${ }^{1}$, A. Alias ${ }^{1}$, R. Alkama ${ }^{1}$, S. Belamari ${ }^{1}$, A. Barbu ${ }^{1}$, A. Boone ${ }^{1}$, \\ F. Bouyssel $^{1}$, P. Brousseau ${ }^{1}$, E. Brun ${ }^{1}$, J.-C. Calvet $^{1}$, D. Carrer ${ }^{1}$, B. Decharme ${ }^{1}$, C. Delire ${ }^{1}$, S. Donier ${ }^{1}$, K. Essaouini ${ }^{2}$, \\ A.-L. Gibelin ${ }^{1, *}$, H. Giordani ${ }^{1}$, F. Habets ${ }^{3}$, M. Jidane ${ }^{2}$, G. Kerdraon ${ }^{1}$, E. Kourzeneva ${ }^{4,5}$, M. Lafaysse ${ }^{1}$, S. Lafont ${ }^{1}$, \\ C. Lebeaupin Brossier ${ }^{1}$, A. Lemonsu ${ }^{1}$, J.-F. Mahfouf ${ }^{1}$, P. Marguinaud ${ }^{1}$, M. Mokhtari ${ }^{6}$, S. Morin ${ }^{1}$, G. Pigeon ${ }^{1}$, \\ R. Salgado ${ }^{7}$, Y. Seity ${ }^{1}$, F. Taillefer ${ }^{1}$, G. Tanguy ${ }^{1}$, P. Tulet ${ }^{8}$, B. Vincendon ${ }^{1}$, V. Vionnet ${ }^{1}$, and A. Voldoire ${ }^{1}$ \\ ${ }^{1}$ CNRM/GAME, UMR3589, Météo-France, CNRS, Toulouse and Grenoble, France \\ ${ }^{2}$ CNRM, Direction de la Météorologie nationale, Casablanca, Morocco \\ ${ }^{3}$ UMR-SIS YPHE, (UPMC, CNRS), Mines-Paristech, Centre de Géosciences, Fontainebleau, France \\ ${ }^{4}$ Russian State Hydrometeorological University, Malookhtisky Pr., 98, 195196, Saint Petersburg, Russia \\ ${ }^{5}$ Finnish Meteorological Institute, P.O. Box 503, 00101, Helsinki, Finland \\ ${ }^{6}$ Office National de la Météorologie (ONM), Algiers, Algeria \\ ${ }^{7}$ Centro de Geofisica de Evora, University of Evora, Evora, Portugal \\ ${ }^{8}$ LACy, UMR8105, Université de La Réunion, CNRS, Météo-France, Saint-Denis, France \\ *now at: the Direction de la Climatologie, Météo-France, Toulouse, France
}

Correspondence to: E. Martin (eric.martin@meteo.fr)

Received: 30 August 2012 - Published in Geosci. Model Dev. Discuss.: 21 November 2012

Revised: 30 April 2013 - Accepted: 27 May 2013 - Published: 16 July 2013

\begin{abstract}
SURFEX is a new externalized land and ocean surface platform that describes the surface fluxes and the evolution of four types of surfaces: nature, town, inland water and ocean. It is mostly based on pre-existing, well-validated scientific models that are continuously improved. The motivation for the building of SURFEX is to use strictly identical scientific models in a high range of applications in order to mutualise the research and development efforts. SURFEX can be run in offline mode (0-D or 2-D runs) or in coupled mode (from mesoscale models to numerical weather prediction and climate models). An assimilation mode is included for numerical weather prediction and monitoring. In addition to momentum, heat and water fluxes, SURFEX is able to simulate fluxes of carbon dioxide, chemical species, continental aerosols, sea salt and snow particles. The main principles of the organisation of the surface are described first. Then, a survey is made of the scientific module (including the coupling strategy). Finally, the main applications of the code are summarised. The validation work undertaken shows that replacing the pre-existing surface models by SURFEX in these
\end{abstract}

applications is usually associated with improved skill, as the numerous scientific developments contained in this community code are used to good advantage.

\section{Introduction}

Accurate simulations of fluxes at the earth's surface are needed for a large number of applications ranging from surface monitoring and hydrology to numerical weather prediction and global climate simulations. Among others, these fluxes include sensible and latent heat fluxes, and fluxes of momentum, carbon dioxide, chemical species, continental aerosols, sea salt and snow particles. For example, in hydrological applications, accurate estimates of surface and bottom runoff are important, as are the possible feedbacks from the hydrological components of the systems to the surface, the atmosphere and the ocean (through interactions between the water table and the root zone, flooded areas or routing of water to the ocean). 
For these reasons, surface models continue to increase in complexity and accuracy as a result of improvements to existing process parameterization or the addition of new processes. Examples of such models include CLASS (Verseghy et al., 1991), CLM (Lawrence et al., 2011), JULES (Best et al., 2011; Clark et al., 2011), LIS (Kumar et al., 2006), Noah (Ek et al., 2003), ORCHIDEE (Krinner et al., 2005), and TESSEL (Balsamo et al., 2009). Much effort has been put into the development of land data assimilation systems at various scales: from continental scale (e.g. Mitchell et al., 2004) to global scale (e.g. Rodell et al., 2004), based on various land-surface models. The recent improvements in these models draw more and more benefits from multidisciplinary research and need highly flexible community codes so that the same code can be used for various applications. This is the only option if code duplications and errors in recoding between applications are to be avoided.

Taking advantage of the continuous development of the surface models ISBA (Noilhan and Planton, 1989) and TEB (Masson, 2000), and their coupling to both the atmospheric models Meso-NH (Lafore et al., 1998), ARPEGE (Courtier et al., 1991), ALADIN (Fischer et al., 2005), AROME (Seity et al., 2011; Brousseau et al., 2011), ALARO (Gerard et al., 2009; Hamdi et al., 2012), and the hydrological models TRIP (Decharme et al., 2008) and MODCOU (Habets et al., 2008), the construction of a fully externalized surface scheme (i.e. a unique code that can be run in coupled and offline configurations) was undertaken. This surface scheme, SURFEX (from the French "Surface externalisée"; Fig. 1; www.cnrm.meteo.fr/surfex/), was built with the following specifications:

1. Include parameterizations for all components of the surface (ocean and land surface, including urban areas and inland water) and simplified parameterizations for theoretical studies.

2. Provide an interface with physiographic databases allowing the creation of various domain types (from point scale to various domain configurations).

3. Include a data assimilation component for numerical weather prediction applications and land-surface monitoring.

4. Preserve a single scientific code for all the surface applications (offline or fully coupled with several atmospheric models).

An additional constraint in the building of SURFEX is that it is designed for a wide range of applications: point scale research simulation, 2-D offline applications at regional, continental and global scale including the coupling with hydrological models, mesocale to global applications within various atmospheric models including operational weather prediction and long climate runs. Assimilation is used in both the numerical weather prediction chain and in the framework

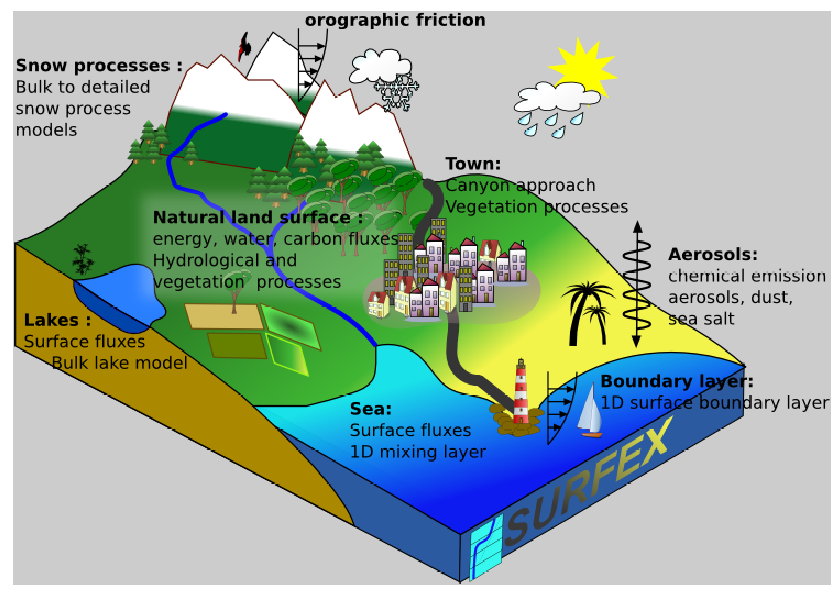

Fig. 1. Schematic representations of the main processes and functionalities of SURFEX.

of a land data assimilation system. The system needs to be modular, highly flexible with clearly specified interfaces.

The objective of this paper is to describe the present status of SURFEX (version 7.2). This is the first article of this type on SURFEX and it summarises the main features of the present state of the code, whose development began nearly $10 \mathrm{yr}$ ago. The main principles of the model and the link with physiographic databases are described in Sects. 2 and 3, respectively. Then the physical schemes and their options are described in Sect. 4. Section 5 is devoted to chemistry, aerosols and sea salt. The strategy for coupling with atmospheric and hydrological models is described in Sect. 6. The assimilation is described in Sect. 7. Finally, Sect. 8 reviews the evaluation of the model and gives some examples of applications.

\section{Main principles of the model}

Due to its multiple uses, SURFEX is built in a modular way to allow an easy implementation of new technical and scientific features. The entry points of SURFEX are PGD (to prepare the physiographic data), PREP (to initialise prognostic variables), RUN (for offline and inline simulations) and ASSIM (for assimilation Fig. 2.). The code is written in FORTRAN90, which is a higher level of the code using strict coding norms identical for all tiles/patches and is devoted to the coupling with the atmosphere, aggregation/disaggregation of fluxes and the calling of the scientific models. Diagnostics are coded in a similar way for all tiles. Various input/ouput formats depending on the host model are available.

SURFEX can be run on linux personal computers up to supercomputers in case of large runs, especially when used in an atmospheric model or on a global scale. SURFEX can be used in parallelized models, in this case the parallelisation is governed by the host model. Parallelization is also possible in offline mode for the mode RUN. However, some components 


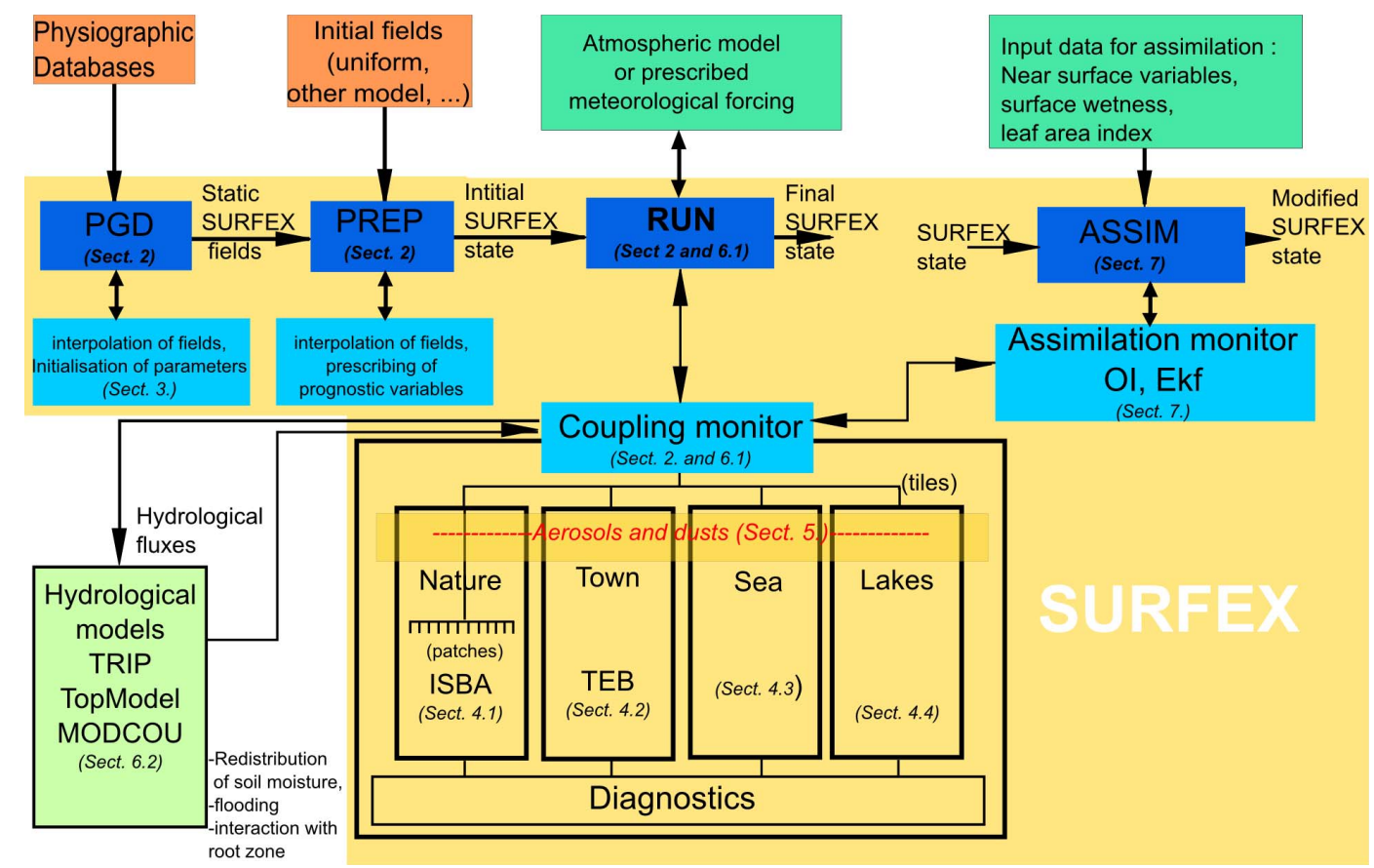

Fig. 2. Schematic representation of the main scientific and technical components of SURFEX (on a yellow background) and their interaction with other models and data.

are not yet parallelized, which is a limitation when SURFEX is used on large grids.

\subsection{The tiling aproach}

An accurate estimation of surface fluxes over a wide range of spatial resolutions needs to account for subgrid heterogeneities (Essery et al., 2003). SURFEX offers the possibility to use tiles or to aggregate the surface parameters for lumped runs. Four main tiles are defined:

1. continental natural surfaces ("nature" tiles) including bare soils, rocks, permanent snow, glaciers, natural vegetation and agricultural landscapes;

2. town (including buildings, roads and transportation infrastructures, gardens);

3. inland water (including lakes and rivers);

4. sea and ocean.

In order to account for heterogeneity within the continental natural surfaces, this tile can be divided into "subtiles" (referred to as patches in what follows, Fig. 3.). A maximum of twelve patches which correspond to the plan functional types described in ECOCLIMAP (Table 1) can be described by SURFEX to account for the variety of soil and vegetation behaviour within a grid point. This allows non-vegetated surfaces (bare soil, rocks, permanent snow) to be treated separately and accounts for the main plant functional types (trop-
Table 1. Patches used for the description of the nature continental tile.

\begin{tabular}{ll}
\hline Bare soil & C3 crops \\
Rocks & C4 crops \\
Permanent snow & Irrigated crops \\
Needle leaf trees & Herbaceous \\
Evergreen broadleaf trees & Tropical herbaceous \\
Deciduous broadleaf trees & Wetlands \\
\hline
\end{tabular}

ical vs. temperate vegetation, low vs. tall vegetation, deciduous vs. evergreen trees, various types of crops, etc.). In the tiling approach, each tile has the same meteorological forcing, while the model prognostic variables (liquid water content, surface temperature, snow cover) and model parameters (soil depth, roughness length, LAI, etc.) and the corresponding fluxes are different.

The tiling is defined by the user and is quite flexible (the number of patches can vary from 1 to 12 ), lakes can be accounted for or not, the town can be represented using the TEB model or as rocks. Aggregation laws were defined by Noilhan et al. (1997) and Noilhan and Lacarrère (1995) for surface and soil parameters,. However, schemes accounting for the carbon cycle must be run with twelve patches, as the definition of aggregated effective parameters for such models is not straightforward. 


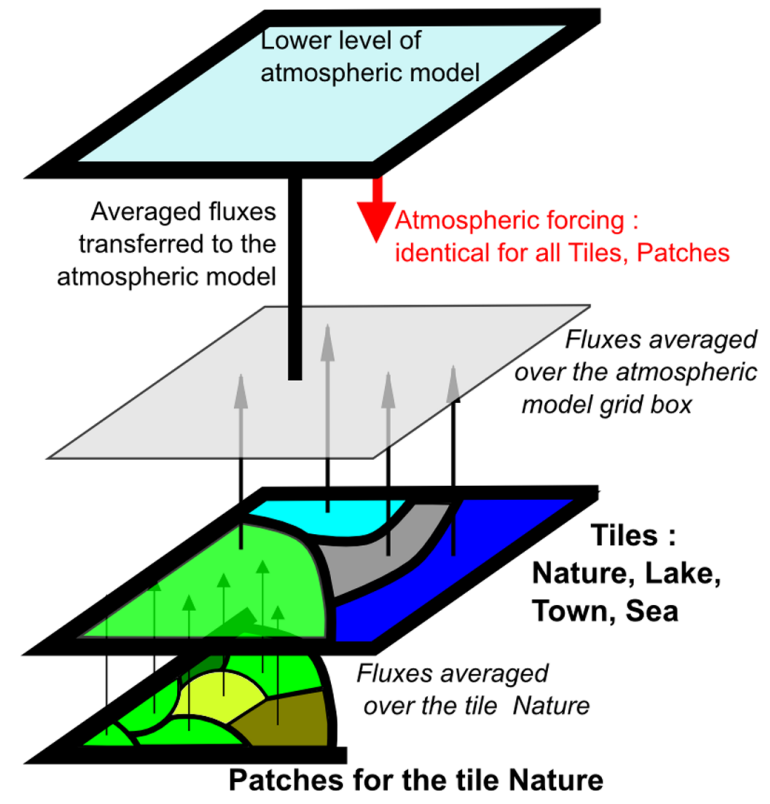

SURFEX tiling and coupling with an atmospheric model

Fig. 3. Schematic representation of the organisation of the surface using four main tiles and patches for nature (soil and vegetation tile).

\section{Physiographic data}

SURFEX is fully coupled with the global, $1 \mathrm{~km}$ resolution, land cover database ECOCLIMAP. The original version (ECOCLIMAP1) is described by Masson et al. (2003). Versions with improvements over western Africa (Kaptué Tchuenté et al., 2010) and Europe (Faroux et al., 2013) were developed later. The ECOCLIMAP database is composed of more than 550 cover types all over the world. Each cover is an ensemble of pixels with similar surface characteristics (e.g. sea, lakes, vegetated areas, suburban areas, etc.). They also account for the vegetation variability that depends on location, climate and phenology. This classification was established using land cover maps and satellite data.

The classification is complemented by look-up tables that allow the parameters for all physical schemes of SURFEX to be retrieved from the ECOCLIMAP covers:

1. Fraction of the surface occupied by each tile (sea, inland water, nature or town).

2. Urban parameters: characteristics concerning buildings and roads. vegetation properties of gardens.

3. Primary parameters for natural continental surfaces that depend on the cover and are defined for each of the 12 patches described in Table 1. These are the leaf area index (LAI), the height of trees and the soil depth (surface, root and deep zones).
4. Secondary parameters that mainly depend on the patches (i.e. identical values for a given patch all over the world): vegetation fraction, emissivity, etc.

The covers are interpolated over the chosen grid. Then all urban, primary and secondary parameters are computed and aggregated if the number of patches is lower than 12 . The town garden areas can be included in the nature tile or in the town tile (allowing for interaction with buildings). Some types of cover can be changed: lakes can be removed and replaced by nature and towns can be replaced by rocks.

Other physiographic datasets are needed by SURFEX:

1. Topography (e.g. Gtopo30 at $1 \mathrm{~km}$, Gesch et al., 1999, or SRTM, Farr et al., 2007, for higher resolution, from which the mean grid-cell altitude and sub-grid topography parameters are derived).

2. Soil properties (clay and sand proportions, organic matter) derived from, e.g. FAO (FAO, 2006) or HWSD (Nachtergaele et al., 2012) databases.

3. Lake depth (Kourzeneva et al., 2012).

4. Ocean Bathymetry (e.g. Etopo2 by Smith and Sandwell, 1997).

The databases cited above are fully interfaced with SURFEX, but all parameters can be prescribed separately by the user. SURFEX is not limited to a particular database, hence databases other than those cited here can be used provided that they are put on a format that can be read by SURFEX.

\section{Description of the physical models for land and ocean surface processes}

\subsection{The Interaction Soil-Biosphere-Atmosphere (ISBA) land surface model}

The evolution of the soil and vegetation biophysical variables within the nature tiles, and their interactions with the atmosphere, are computed by the ISBA land surface model (LSM). ISBA has evolved considerably since its original formulation by Noilhan and Planton (1989). The original forcerestore method was developed in order to capture first-order processes critical to numerical weather prediction while optimizing the input parameters and minimizing the land surface computations. However, over the last two decades, the demands of the user and research communities, and also computational resources, have grown considerably. ISBA has been progressively enriched with more detailed representations of processes in all compartments of the model. This section describes the model physical parameterizations and options (summarised in Table 2) currently available in ISBA. 
Table 2. Summary of the main parameterizations available in ISBA.

\begin{tabular}{|c|c|c|}
\hline Model component & Parameterisation & References \\
\hline \multirow{5}{*}{$\begin{array}{l}\bar{\sigma} \\
\dot{\mathscr{s}}\end{array}$} & Force restore: two layers (2L) & Noilhan and Planton (1989), Mahfouf and Noilhan (1996) \\
\hline & Force restore: three layers (3L) & Boone et al. (1999) \\
\hline & Explicit multilayer scheme (DIF) & Boone (2000), Decharme et al. (2011) \\
\hline & Soil water phase changes & Boone et al. (2000) \\
\hline & Hydraulic conductivity profile & Decharme et al. (2006) \\
\hline \multirow{4}{*}{ 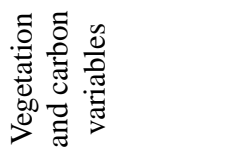 } & Standard evapotranspiration (forced LAI) & Noilhan and Planton (1989) \\
\hline & Photosynthesis and $\mathrm{CO}_{2}$ fluxes (forced LAI) & Calvet et al. (1998) \\
\hline & Biomass evolution & Calvet et al. (1998), Gibelin et al. (2006) \\
\hline & Biomass evolution and terrestrial carbon cycle & Gibelin at al. (2008) \\
\hline \multirow{5}{*}{ 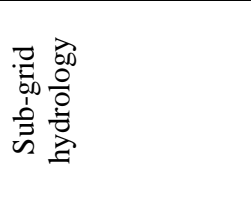 } & Runoff over saturated areas (Dunne): VIC & Habets et al. (1999a) \\
\hline & Runoff over saturated areas (Dunne): TOPMODEL & Decharme and Douville (2006a) \\
\hline & Infiltration excess runoff (Horton) & Decharme and Douville (2006a) \\
\hline & Residual drainage & Habets et al. (1999b) \\
\hline & Spatial heterogeneities in rainfall intensities & Decharme and Douville (2006a) \\
\hline \multirow{3}{*}{ 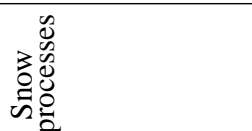 } & Single layer bulk snow model & Douville et al. (1995), Bazile et al. (2001) \\
\hline & Intermediate complexity: ISBA-ES & Boone and Etchevers (2001) \\
\hline & Detailed model: CROCUS & Vionnet et al. (2012), Brun et al. (1989, 1992) \\
\hline
\end{tabular}

\subsubsection{Surface energy budget}

The ISBA surface energy budget is computed using a soilvegetation composite approach. A single surface temperature is used in the computation of the surface energy balance of the land/cover system (Noilhan and Planton, 1989). The surface heat flux, $G\left(\mathrm{~W} \mathrm{~m}^{2}\right)$, into this soil-vegetation-snow composite is equal to the sum of all the surface-atmosphere energy fluxes: the net radiation $\left(R_{\mathrm{n}}\right)$, the sensible heat flux $(H)$ and the latent heat flux (LE). $R_{\mathrm{n}}$ is the sum of the net short-wave radiation and the net long-wave radiation computed using surface composite soil-vegetation-snow albedo and emissivity. $H$ is calculated by means of the Louis (1979) aerodynamics formulae depending upon the thermal stability of the atmosphere, modified by Mascart et al. (1995) in order to consider different roughness length for heat and momentum. Finally, LE is related to the sum of evaporation from the bare soil surface, sublimation from the snow pack and from soil ice, and evapotranspiration from the vegetation. More details can be found in Noilhan and Planton (1989), Douville et al. (1995) and Boone et al. (2000).

The surface soil-vegetation temperature $\left(T_{\mathrm{S}}\right)$ is approximated as the temperature of a thin superficial layer having a depth fixed at $0.01 \mathrm{~m}$. It varies according to the surface heat flux $(G)$ and a soil heat flux. The latter depends on the soil scheme (see Sect. 4.1.2 for more details on the soil schemes). In the case of the force-restore approach (Noilhan and Planton, 1989), $T_{\mathrm{s}}$ is restored towards its mean value over one day as proposed by Bhumralkar (1975) and Blackadar (1976). It also depends on the surface composite thermal inertia coefficient, which is parameterized as the harmonic mean of soil (with or without soil ice), snow and vegetation thermal inertia coefficients (weighted by surface vegetation and snow fractions; Noilhan and Planton, 1989; Douville et al., 1995; Boone et al., 2000). If an explicit multi-layer soil scheme (Boone, 2000; Decharme et al., 2011) is used, the surface soil-vegetation temperature $\left(T_{\mathrm{S}}\right)$ varies according to the surface heat flux $(G)$ and the soil heat flux calculated by combining the thermal gradient between the thin superficial layer and the second soil layer with the soil properties.

\section{Surface energy budget in the presence of snow}

In the case of one-layer bulk snow models, the force-restore composite surface temperature also accounts for snow. But when explicit multi-layer snow schemes are used (ISBA-ES or Crocus see Sect. 4.1.4), the surface energy budget is computed as the sum of the soil-vegetation composite energy budget and the snow energy budget weighted by the snow fraction (Boone and Etchevers, 2001). In this case, the "radiative" surface temperature is computed using the composite soil-vegetation and the snow surface temperatures. This option is always used with the ISBA multi-layer soil diffusion scheme (Boone et al., 2000; Decharme et al., 2011). Note that bulk snow schemes cannot be used with explicit multi-layer soil schemes.

\subsubsection{Soil}

\section{Force restore approach}

In this approach, the surface temperature is restored towards a restore temperature, accounting for the soil heat flux. The 
so-called restore temperature is representative of the layer affected by a daily damping depth. For longer term simulations, there are two options to prevent model drift. The first method is to prescribe an external deep layer temperature. The restore temperature is itself restored to this temperature, which can be based on observational data and can be constant or time varying. The second method is a multilayer forcerestore approach, each layer accounting for a given timescale (from 1 day to $1 \mathrm{yr}$ ). The latter method is applied for long climate runs. Note that, in the configurations mentioned above, the thermal properties between the surface and the base of the restore layer(s) are assumed to be vertically homogeneous.

The vertical soil water transfer is represented by either two (2L) or three (3L) layers based on the force-restore method proposed by Deardorff (1977). The volumetric water content of the surface superficial layer (first layer) is restored towards the volumetric water content of the combined bulk surface and rooting layer (second layer). A set of force-restore coefficients were computed by Noilhan and Planton (1989) using hydraulic parameter values from Clapp and Hornberger (1978) based on either a simple analytical solution relying on Darcy's law or a calibration using a high resolution onedimensional model representation of Richard's equation.

In addition to the classic force-restore approach described above, several improvements have been made. A gravitational drainage coefficient has been added, which relaxes the water content to the field capacity value when this value is exceeded (Mahfouf and Noilhan, 1996), where the field capacity is the volumetric water content corresponding to a gravitational drainage of $0.1 \mathrm{mmday}^{-1}$ (Wetzel and Chang, 1987). The $3 \mathrm{~L}$ version accounts for a third sub-root-zone layer to better represent the vertical soil moisture gradient in the vadose zone, so an additional calibrated coefficient has been added to represent the diffusion between the root zone and the sub-root zones (Boone et al., 1999). If the water content of the bulk root or deep layers exceeds the soil porosity, a saturation excess runoff is generated. Note that this form of runoff is less likely when a sub-grid hydrological option is used (see Sect. 4.1.5). Finally, soil water can be extracted from the root zone for transpiration until the soil water decreases to the wilting point volumetric water content (corresponding to a matrix potential of -15 bar). Bare soil evaporation can continue at water contents below wilting point, depending on both moisture and temperature, by water vapour transfer (Braud et al., 1993; Giard and Bazile, 1996). Finally, all force-restore coefficients and soil hydrological parameters are related to soil textural properties and moisture using the continuous relationships from Noilhan and Lacarrère (1995), which were derived from the Brooks and Corey (1966) model and the Clapp and Hornberger (1978) parameters (Noilhan and Planton, 1989; Noilhan and Mahfouf, 1996; Boone et al., 1999).

\section{Explicit multilayer soil scheme}

In contrast to the force-restore method, the surface and subsurface layers are coupled via an explicit heat flux computation based on the classical one-dimensional Fourrier law. The total soil heat capacity is computed as the sum of both water and soil matrix heat capacity. Following Johansen (1975), Farouki (1986) and Peters-Lidard et al. (1998), and the soil thermal conductivity is expressed as a function of volumetric water and ice contents, soil porosity and dry soil conductivity. The surface and soil temperatures are computed using a method that permits fully implicit coupling with the atmosphere (see Sect. 6.1.1).

The explicit soil hydrology uses the so-called "mixed" form of the Richards equation to simulate the vertical water mass transfer within the soil via Darcy's law. The water evolution is solved in terms of volumetric water, the hydraulic gradient being solved in terms of water pressure head. This mixed form is generally considered superior to the pressurebased or moisture-based forms because it maintains a high accuracy mass balance. In addition, the mixed form is applicable to homogeneous or heterogeneous soils and to saturated or unsaturated soils (Milly, 1985; Decharme et al., 2011). The relationship between soil moisture, soil matrix potential, and hydraulic conductivity is determined using the Brooks and Corey (1966) relationships. For dry soils, water vapour transfer can be significant and maintain evaporation from the soil. Therefore, vapour and liquid water conductivity are summed, resulting in an effective conductivity. This depends on the soil texture, water content, and temperature (Braud et al., 1993). The water transfer between two layers depends on the inter-layer effective hydraulic conductivity (geometric mean between the conductivity of the two layers). This method reduces the weighting error, improves the hydraulic transfer between layers, and is generally applicable in all situations of moisture gradient (Decharme et al., 2011). Water sinks include water extraction owing to evapotranspiration and gravitational drainage. Soil evaporation is drawn from the superficial layer, while transpiration is removed throughout the root zone using an exponential distribution of roots (Jackson et al., 1996). Water sources include condensation on the surface layer, a possible mass influx at the lower boundary (when coupled to an aquifer model), and infiltration, which is parameterized via a Green and Ampt (1911) approach.

Richard's equation is solved numerically using the CrankNicolson implicit time scheme where the implicit vertical flux terms are linearized using a first-order Taylor series expansion. The resulting linear set of diffusion equations can be cast in a tri-diagonal form and solved quickly. This type of algorithm is considerably less expensive than an iterative method and is more suitable for regional to global large-scale applications. For large time steps, such as in a global climate model, a linear time splitting option is also activated, which further improves numerical stability. 
Most LSMs use a zero heat flux lower boundary condition, the soil must be sufficiently deep with respect to the duration of the simulation in order to prevent model drift. For this reason, the soil thermal computations use additional layers compared to the soil hydrological computational grid. To compute the heat capacity and thermal conductivity of these additional layers, the soil moisture is extrapolated downward assuming hydrostatic equilibrium in order to save computer time and while maintaining good hydrological simulations (e.g. river flow).

The default diffusion configuration of the model uses 14 layers to represent $12 \mathrm{~m}$ depth. Eight of these layers are in the top metre of the soil since Decharme et al. (2011) has shown that this was the minimum number of layers required to maintain a robust numerical solution of the Richards equation.

\section{Hydraulic conductivity profile}

ISBA can account for the effect of soil heterogeneities on the vertical soil water transfer by using an exponential profile of the saturated hydraulic conductivity, $k_{\text {sat }}$, with soil depth for both the force-restore and diffusion schemes. The main hypothesis is that roots and organic matter favour the development of macropores and enhance the water movement near the soil surface, and that soil compaction is an obstacle for vertical water transfer in the deeper soil. This parameterization (described in detail by Decharme et al., 2006) depends on only two parameters, which represent the rate of decline of the $k_{\text {sat }}$ profile and the depth where $k_{\text {sat }}$ reaches its socalled "compacted value". The first parameter can be related to soil properties but cannot exceed $2 \mathrm{~m}^{-1}$, and the second is assumed to be equal to the rooting depth. These two parameters can also be tuned to improve streamflow forecasts (Quintana Seguí et al., 2009).

\section{Soil water phase changes}

Soil ice increases when water and energy are available for ice production. In contrast, the soil ice decreases due to melting and/or sublimation. During phase changes, the total soil water content for each soil layer is conserved, so as a soil freezes (resp. thaws), the liquid water content will decrease (resp. increase), corresponding to an increase (resp. decrease) in soil ice content. Since the surface is a composite layer, a surface insulation coefficient is introduced in order to partition the available energy into a portion which causes soil water phase changes and a part which heats or cools the vegetation (Giard and Bazile, 2000). A characteristic timescale for phase changes is also introduced in order to prevent a time step dependence of the phase change. In order to avoid a computationally intensive iterative solution procedure, the soil temperature profile is first calculated, then the phase change term is evaluated and temperatures are adjusted accordingly.
There are two methods available for soil water phase change. The first option corresponds to a simple energylimited method (Giard and Bazile, 2000; Boone et al., 2000) which consists of freezing water whenever the soil temperature falls below the freezing point, and melting soil ice when this temperature is exceeded. This simple method was developed in order to reproduce the first-order effects of phase change on surface fluxes and lower atmospheric variables within the context of a force-restore approach. The second method determines a maximum liquid water content as a function of temperature using the Gibbs free energy concept (similar to that proposed by Cherkauer and Lettenmaier, 1999). Using this method, the soil phase changes follow the so-called soil specific freezing characteristic curve, so that liquid water can exist at sub-freezing temperatures. The relation between the soil water potential and temperature for sub-freezing conditions is from Fuchs et al. (1978), and the Brooks and Corey (1966) model is used to transform the soil matrix potential in the presence of ice into the maximum unfrozen (liquid) water content. This method is more physically based than the simple energy-limited method, and is more consistent with the multilayer soil option. It is better suited for longer timescale applications.

In terms of hydrology, soil ice has the effect of decreasing the hydraulic conductivity relative to a thawed soil with the same total soil moisture, since freezing-thawing can be modelled as drying-moistening to a good approximation (Kane and Stein, 1983; Spans and Baker, 1996). Therefore, as a soil freezes, ice is assumed to become part of the soil matrix, thereby reducing the soil porosity (Boone et al., 2000). Note that very large liquid water gradients can develop when significant soil water freezing occurs, so an ice impedance coefficient is calculated following Johnsson and Lundin (1991) and used to prevent an overestimation of the upward liquid water flux at the freezing front.

\subsubsection{Vegetation and carbon variables}

\section{Photosynthesis and $\mathrm{CO}_{2}$ fluxes}

The standard version of ISBA uses the simple Jarvis (1976) approach to estimate the evapotranspiration. This approach is based on four factors accounting for the photosynthetically active radiation, the water stress, the water vapour deficit and an air-temperature dependence on the surface resistance. In contrast, photosynthesis and surface $\mathrm{CO}_{2}$ fluxes are comprehensively modelled by ISBA-A-gs. ISBA-A-gs is a $\mathrm{CO}_{2}-$ responsive LSM able to simulate the diurnal cycle of carbon and water vapour fluxes (Calvet et al., 1998; Gibelin et al., 2006). It is based on a photosynthesis-driven representation of the leaf stomatal conductance based on the model of Goudriaan et al. (1985) modified by Jacobs (1994) and Jacobs et al. (1996). This parameterization is derived from the set of equations commonly used in other land surface 
models (Farquhar et al., 1980, for C3 plants and Collatz et al., 1992, for C4 plants) and it has the same formulation for $\mathrm{C} 4$ plants as for $\mathrm{C} 3$ plants, differing only by the input parameters. Moreover, the slope of the response curve of the lightsaturated net rate of $\mathrm{CO}_{2}$ assimilation to the internal $\mathrm{CO}_{2}$ concentration is represented by the mesophyll conductance $\left(g_{\mathrm{m}}\right)$. Therefore, the value of the $g_{\mathrm{m}}$ parameter is related to the activity of the Rubisco enzyme (Jacobs et al., 1996) while, in the model by Farquhar et al. (1980), this quantity is represented by a maximum carboxylation rate parameter $V_{\mathrm{C} \text {, max }}$. The model also includes a detailed representation of the soil moisture stress. Two different types of drought responses are distinguished for herbaceous vegetation (Calvet, 2000) and forests (Calvet et al., 2004), depending on the evolution of the water use efficiency (WUE) under moderate stress: WUE increases in the early soil water stress stages in the case of the drought-avoiding response, whereas it decreases or remains stable in the case of the drought-tolerant response. In all cases, the soil moisture deficit impacts $g_{\mathrm{m}}$, which permits the limitation of photosynthesis during water stress to be described (Galle et al., 2009) in conjunction with other environmental factors such as leaf temperature or the leaf-to-air saturation deficit. It should be noted that, unlike the Jarvis-type parameterization used in the initial version of ISBA (Noilhan and Planton, 1989), the model parameters of heterogeneous grid-cells cannot be aggregated. Instead, simulations must be performed over all patches.

\section{Biomass evolution, carbon allocation and leaf phenology}

ISBA-A-gs simulates the leaf biomass and the LAI (defined as the leaf area per unit ground area), using a simple growth model (Calvet et al., 1998). On a daily timestep, the leaf biomass is supplied with the carbon assimilated by photosynthesis during the course of the day, and decreased by turnover and respiration terms. LAI is inferred from the leaf biomass multiplied by the specific leaf area (SLA), which depends on the leaf nitrogen concentration (Calvet and Soussana, 2001; Gibelin et al., 2006).

Unlike most other land surface and vegetation models, there is no phenology module based on the accumulation of favourable days (like growing degree days for temperate deciduous phenology for instance). The phenology is directly the result of the photosynthetic activity and leaf mortality.

\section{Ecosystem respiration}

The net ecosystem exchange (NEE) of $\mathrm{CO}_{2}$ results from the balance between photosynthesis (or gross primary production, GPP) and the ecosystem respiration $\left(R_{\text {eco }}\right)$. In ISBA-A$\mathrm{gs}$, the latter is calculated using a simple $Q_{10}$ response to soil temperature, weighted by surface soil moisture (Albergel et al., 2010a). For natural vegetation, the basal $R_{\text {eco }}$ rate can be calibrated to obtain an equilibrium between the accumulated $R_{\text {eco }}$ and GPP, on an annual or multi-annual basis. As opposed to the ISBA-CC model (see below), the various autotrophic and heterotrophic respiration terms are not calculated.

\section{Terrestrial carbon storage}

Gibelin et al. (2008) developed the ISBA-Carbon Cycle (ISBA-CC) LSM in order to simulate the main components of the terrestrial carbon cycle. ISBA-CC is based on ISBA-Ags and provides a number of additional variables representing the vegetation biomass (wood and root compartments), the above- and below-ground litter pools and the soil carbon pools. ISBA-CC uses the carbon fluxes, and the leaf growth and senescence calculated by ISBA-A-gs to simulate the biomass in the wood and roots compartments. Biomass resulting from photosynthesis (minus leaf respiration) is first entirely allocated to leaves and twigs by the ISBA-A-gs module. It is then translocated to the other biomass pools at rates depending on the growth or senescence states of the plant, and the respiration of the pool. The litter and soil biogeochemistry module included in ISBA-CC is based on the wellknown CENTURY model (Parton et al., 1987) that partitions the soil carbon among pools with different residence times. Since the autotrophic and heterotrophic respiration terms are calculated, the net primary production (NPP) can be simulated. In the case of forests, the wood biomass growth is simulated and equilibrium climax biomass values can be determined. There is no representation of disturbance, whether natural or of human origin; for example, a forest management module would need to be implemented in order to represent the carbon sink due to forest re-growth (Bellassen et al., 2010).

\subsubsection{Snow}

The snow component of LSMs in use by the atmospheric research community is generally classified into three levels of general model complexity (Boone and Etchevers, 2001; Armstrong and Brun, 1998). Simple composite force-restore (e.g. Douville et al., 1995; Yang et al., 1997) or singlelayer bulk snow (e.g. Verseghy, 1991; Slater et al., 1998) schemes attempt to model the main effects of snow cover on the atmosphere using very simple first-order snow physics. At the other end of the spectrum are explicit internal-snowprocess models which use multiple layers with a relatively fine vertical resolution and detailed physical parameterization schemes (e.g. Anderson, 1976; Jordan, 1991; Brun et al., 1992; Bartelt and Lehning, 2002). Applications of such models have so far mostly included avalanche forecasting and detailed local-scale studies. Finally, explicit snow schemes of intermediate complexity are based on the complex models but with fewer layers and similar but generally simplified processes (e.g. Loth et al., 1993; Lynch-Stieglitz, 1994; Boone and Etchevers, 2001). Such models were designed to bridge the gap between the detailed schemes and the simple 
models for meso- to large-scale meteorological and hydrological applications, limiting the computation costs and simplifying the initialization issues (see Essery et al., 2013 for a comprehensive overview of the current state of the art of snow modelling). SURFEX currently contains three snow model options, which cover the entire spectrum of the model complexity mentioned above, and the users make their choice according to the scientific goals, computing resources and evaluation data available for a particular study.

\section{Single layer bulk snow models}

Two options using the so-called first-order schemes are available (Douville et al., 1995; Bazile et al., 2001) and have been used extensively for global climate and numerical weather prediction applications. Both schemes use the compositesurface method based on the force-restore approach, and they contain three prognostic variables for a single-layer snow pack: the snow water equivalent (SWE), the average snow cover bulk density and an age-dependent snow albedo. Some noteworthy distinctions can be made between the two models. In Douville et al. (1995), the surface thermal inertia includes a contribution from the snow thermal properties, the minimum snow albedo is 0.50 , the surface temperature used to compute snowmelt is linearly related to the restore temperature by the vegetation fraction, and the vegetation snow cover fraction depends on the vegetation aerodynamic roughness length. In Bazile et al. (2001), the surface thermal inertia is unchanged by the presence of a snow cover, the minimum snow albedo is 0.65 , the snow-melt energy is directly computed using the surface temperature and the vegetation snow cover fraction depends on LAI and snow age. In both cases, in the presence of permanent snow or glacier, the minimum snow albedo is higher than in the case of seasonal snow.

\section{Intermediate complexity model: ISBA-Explicit snow}

ISBA-Explicit Snow (ISBA-ES: Boone and Etchevers, 2001) was designed for implicit coupling with atmospheric models and spatially distributed hydrological modelling applications. There are three variables saved at each time step that are used to describe the state of the snow for multiple layers: the heat content (or specific enthalpy), the snow density, and the layer thickness. The snow albedo constitutes a fourth prognostic variable (which is the same as in Douville et al., 1995). In terms of the number of snow layers, the default value is three (the minimum number to capture vertical gradients of density and temperature for most climate conditions) but some applications use up to 10 layers. Key processes represented include transmission of radiation within the snowpack, freeze-thaw, compaction and settling, and liquid water storage and through-flow. The snowpack is coupled to the underlying ground through a heat flux term in which the interfacial thermal conductivity represents both snow and soil-vegetation thermal properties.

\section{Explicit internal-snow-processes model: Crocus}

Crocus was primarily developed for the detailed study of the snowpack evolution at a particular location, and for operational avalanche prediction (Brun et al., 1989, 1992). It models the snow stratigraphy using a one-dimensional finiteelement grid. The number of layers depends on a set of specific rules intended to properly capture the snowpack layering dynamics by representing the vertical gradients of the snowpack with high resolution. Each snow layer is described by its thickness, temperature, density, liquid water content, grain types (dendricity, sphericity, size, and age), and a historical variable that indicates whether there has been liquid water or faceted crystals in the layer. In addition, Crocus takes the slope angle of the surface into account when computing the compaction. The impact of drifting snow on compaction, metamorphism and sublimation can also be taken into consideration. Crocus has recently been rewritten to match the ISBA-ES structure and interfaces within SURFEX. The model is driven by meteorological variables observed, analysed, or modelled at the snow surface, or it can be implicitly coupled with an atmospheric model. The coupling with the underlying ground is identical to that used by ISBA-ES. See Vionnet et al. (2012) for an up to date, comprehensive overview of Crocus in SURFEX.

\subsubsection{Subgrid hydrology}

At regional or global scale, the land surface water budget is calculated on grid cells with sides that typically measure from several $\mathrm{km}$ to $300 \mathrm{~km}$. At such a resolution, the sub-grid distribution of the atmospheric fluxes and land surface characteristics has a significant impact on the mean water budget simulated within each grid box. In other words, regional and global hydrological simulations are generally sensitive to the horizontal resolution of the computation grid (Boone et al., 2004; Decharme et al., 2006). Nevertheless, this sensitivity can be reduced in ISBA by using sub-grid parameterizations of the main hydrological processes (Decharme and Douville, 2006a, 2007). In ISBA, five optional parameterizations account for the sub-grid variability of soil moisture, soil maximum infiltration capacity, soil hydraulic properties, precipitation, and/or vegetation properties. Note that all these options are described and validated in detail in Decharme and Douville (2006a):

1. First, the surface runoff over saturated areas, named Dunne runoff, can be computed using one of the two options that attempt to represent soil moisture spatial heterogeneities:

a. The Variable Infiltration Capacity (VIC) scheme (Zhao, 1992; Dümenil and Todini, 1992; Wood et al., 1992; Habets et al., 1999a) in which the saturated fraction of the grid cell depends on soil moisture, precipitation intensity and a shape parameter, 
$B . B$, that can be fixed manually (generally around 0.5 ) or computed using the standard deviation of orography in each grid cell at the model resolution considered (Decharme and Douville, 2007).

b. A simple TOPMODEL (TOPography based MODEL) approach. TOPMODEL attempts to combine the important distributed effects of channel network topology and dynamic contributing areas for runoff generation (Beven and Kirkby, 1979; Silvapalan et al., 1987). This formalism takes topographic heterogeneities into account explicitly by using the spatial distribution of the topographic indices. The coupling between TOPMODEL and ISBA was proposed by Habets and Saulnier (2001) and generalized by Decharme et al. (2006). Its formulation does not require calibration (Decharme and Douville, 2006a).

2. The second mechanism that produces surface runoff is called Horton runoff and occurs for a rainfall intensity that exceeds the effective maximum infiltration capacity of the soil. This process is parameterized using a sub-grid exponential distribution of the soil maximum infiltration capacity. Two maximum infiltration capacity functions proportional to the liquid water and ice content of the soil are used. They enable the Horton runoff to be represented explicitly over unfrozen and frozen soil (Decharme and Douville, 2006a).

3. The third parameterization allows linear residual drainage when the soil moisture of each layer is below the field capacity. The idea is to take the spatial heterogeneity of soil moisture and soil hydraulic properties into account within a grid box (Habets et al., 1999b; Etchevers et al., 2001). This linear residual drainage depends on a coefficient which can be calibrated basin by basin or assumed constant and uniform.

4. The fourth parameterization accounts for spatial heterogeneities in rainfall intensity. As a first-order approximation, this sub-grid variability is given by an exponential probability density distribution. The main assumption is that, generally, the rainfall intensity is not distributed homogeneously over the entire grid cell. A fraction of the grid cell affected by rainfall can then be determined (Fan et al., 1996; Peters-Lidard et al., 1997). This parameterization affects the dripping from the canopy reservoir (Mahfouf et al., 1995) and the two maximum infiltration capacity functions used in the Horton runoff computation (Decharme and Douville, 2006a).

5. Last, the tiling approach in the nature tiles (patches, see Sect. 2) is also a means to account for land cover and soil depth heterogeneities: each sub-grid patch extends vertically throughout the soil-vegetation-snow column.
So, one rooting depth and one soil depth are assigned to each patch. Hence the hydrology response of a grid point is modified.

\subsection{The town energy balance (TEB) model}

Most urban parameterizations follow simplified approaches (Masson, 2006). The most common way to do this is to use a vegetation-atmosphere transfer model whose parameters have been modified. Cities are then modelled as bare soil or a concrete plate. The roughness length is often large (one to a few metres; Wieringa, 1993; Petersen, 1997).

The Town Energy Balance (Masson, 2000; Lemonsu et al., 2004) scheme is the first numerical scheme built following the canyon approach. The physics treated by the scheme is relatively complete. Because of the complex shape of the city surface, the urban energy budget is split into different parts, in such a way that three surfaces are considered: roofs, roads, and walls. This type of approximation has been used in some models (e.g. Martilli, 2002; Kondo et al., 2005), while others choose to keep only two energy balances: roofs and effective canyons (encompassing both walls and roads) (e.g. Best et al., 2006; Dupont and Mestayer, 2006; Porson et al., 2009). All these models simulate more accurate fluxes to the atmosphere than modified-vegetation models. A review and intercomparison of all these models is available in Grimmond et al. $(2010,2011)$. However, when the focus shifts to impacts on the people in the cities (in buildings or on the road) or economics (e.g. energy consumption in buildings), it becomes necessary to clearly separate buildings, canyon air, roads, and, if present, gardens.

The physical processes taken into account in TEB are (Fig. 4):

1. Short-wave and long-wave trapping effect of canyon geometry: up to two reflections between canyon surfaces (walls and road) for long-wave fluxes and an infinite number of reflections for solar radiation are simulated. Shadows of buildings on roads are taken into account.

2. Anthropogenic sensible heat flux: this flux comes either from heated surfaces, or prescribed fluxes from traffic and industry (interacting with the canyon air).

3. Water and snow interception by roofs and roads: the snow cover is simulated using a one-layer scheme derived from the bulk snow model of ISBA, and snow albedo rapidly decreases over time to take account of the fact that snow quickly becomes dirty in urban or road environments.

4. Heat conduction and heat storage in buildings and roads. These are computed using the equation of heat conduction. It allows several distinct layers to be described in the materials. For example, an insulation layer can be included properly in walls, either in the interior of the wall or on the outside. 


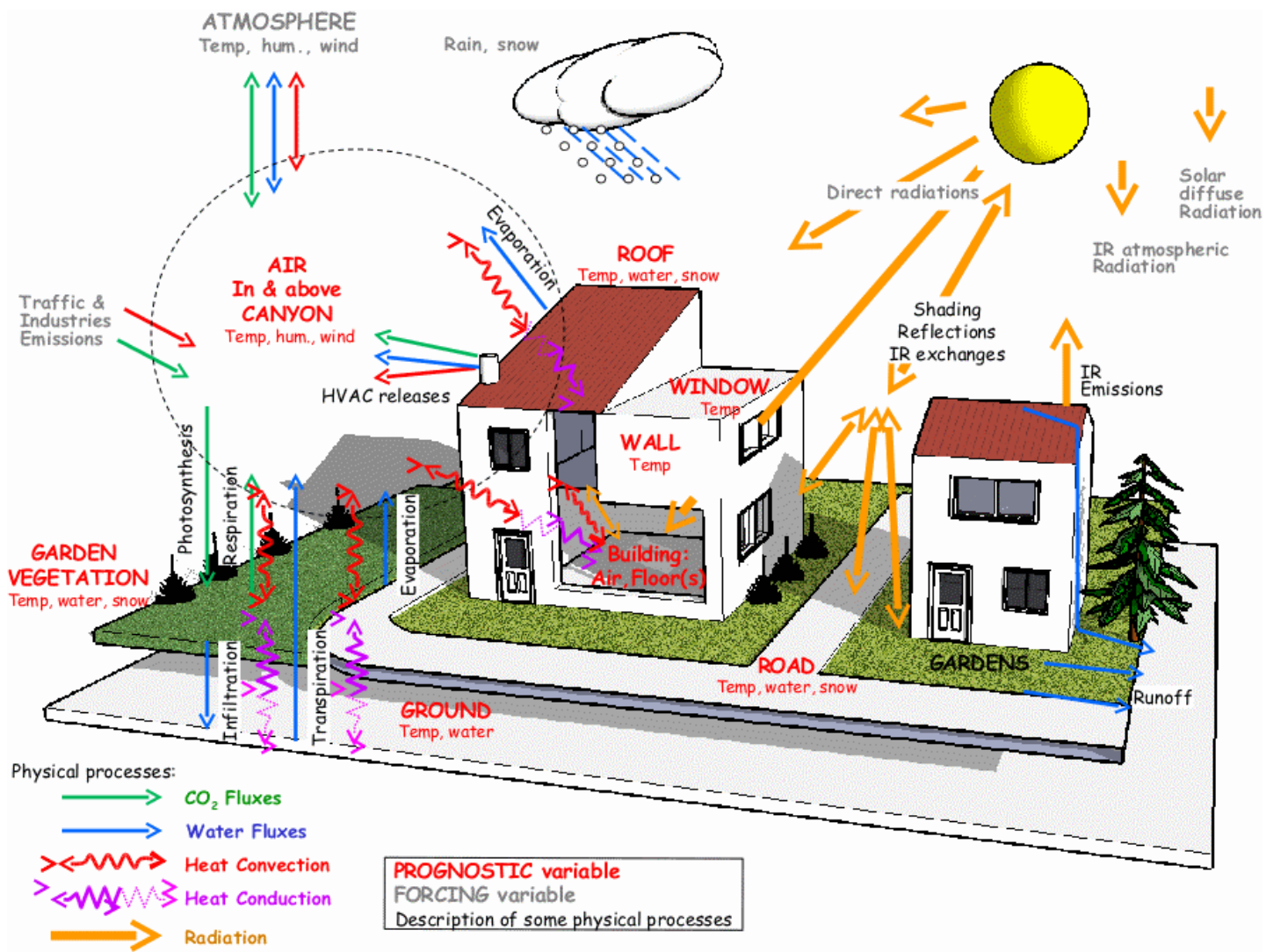

Fig. 4. Schematic representation of the main prognostic variables and processes in the TEB model (HVAC in the figure stands for heatventilation-air conditioning system).

5. Interaction between canyon air and the built surfaces: the canyon micro-climate (temperature, humidity, wind, possibly turbulence) is computed by TEB using either a quasi-equilibrium equation for fluxes (classical approach) or the surface boundary layer scheme (see Sect. 6.1) down to the street. In the latter, buildings produce a drag force on wind, produce additional turbulence, and heat and water fluxes from roofs and walls are directly included at the correct height in and above the canyon. The turbulence mixing length and drag coefficient come from state-of-the art parameterizations developed using computational fluid dynamics (Santiago and Martilli, 2010).

A new feature recently introduced into the model is the ability to include gardens inside the street canyon (whereas they were previously treated separately by ISBA). The physiological behaviour of the plants and the treatment of the soil are still computed by ISBA (to take advantage of all the possibilities of this scheme, including the calculation of $\mathrm{CO}_{2}$ fluxes). In the garden areas, shadows from the buildings now interfere with the vegetation, and the vegetation is in contact with the canyon air. The geometry of the canyon is now better represented (buildings are too close together if gardens are discarded). The gardens improve the simulation of the canyon micro-climate (opening the path to comfort studies), the snowmelt and, more generally, the incoming radiation on building walls (Lemonsu et al., 2012). Further developments will include vegetated roofs and improved internal building energetics (note that the latter is pertinent because the wall energy balance is treated separately from the road). This allows the efficiency to be quantified (in terms of energy consumption or comfort) for scenarios of climate change adaptation in cities.

\subsection{Sea and ocean surfaces}

Surfaces fluxes can be calculated using several models and parameterizations for the estimation of the sea surface temperature (SST) and the turbulent fluxes. Concerning the SST, several options of increasing complexity are available:

1. For short simulations (covering a few days), only a fixed SST may be needed. In this case, sea ice is assumed to be present as soon as the initial SST is below $-2{ }^{\circ} \mathrm{C}$. The sea-ice extent does not change during the run.

2. For longer atmospheric simulations, a 1-D ocean model may be used, provided that horizontal advection can be 
neglected. This model may be used for short periods of time, when strong coupling occurs between the marine atmospheric boundary layer and the ocean mixed layer (e.g. in thunderstorm or hurricane conditions). In the model, the turbulent vertical mixing is based on a parameterization of the second-order turbulent moments expressed as a function of the turbulent kinetic energy (Gaspar et al., 1990). In this formulation, the vertical mixing coefficients are provided by the calculation of two turbulent length scales representing upward and downward conversions of turbulent kinetic energy (TKE) into potential energy. By allowing a response to high frequencies in the surface forcing, the scheme improves the representation of the vertical mixed layer structure, sea surface temperature and upper-layer current (Blanke and Delécluse, 1993). However, this parameterization fails to properly simulate the mixing in strongly stable layers in the upper thermocline (Large et al., 1994; Kantha and Clayson, 1994). Consequently, a parameterization of the diapycnal mixing (Large et al., 1994) was introduced into Gaspar's turbulence parameterization model in order to take the effects of the vertical mixing occurring in the thermocline into account (Josse et al., 1999). This non-local source of mixing, mainly due to internal wave breaking and current shear between the mixed layer and upper thermocline, impacts the temperature, salinity, momentum and turbulent kinetic energy inside the mixed layer, particularly during restratification periods. This parameterization was widely used, for instance, to successfully study the diurnal cycle in the Equatorial Atlantic (Wade et al., 2011), the Equatorial Atlantic cold tongue (Giordani and Caniaux, 2011), and the production of modal waters in the northeast Atlantic (Giordani et al., 2005) or to derive surface heat flux corrections (Caniaux et al., 2005). This model does not include a sea-ice model yet.

3. If climate simulations are to be made over several years or decades, a full 3-D ocean model that solves the oceanic circulation and associated heat transfer is needed. SURFEX does not include such a model. Coupling with an oceanic model in the CNRM-CM5.1 global climate model used for phase 5 of the Coupled Model Intercomparison Project (CMIP) runs (Voldoire et al., 2012) was achieved through the OASIS coupling software (Redler et al., 2010). The sea-ice component was embedded into the ocean model in this case.

Whatever the configuration chosen, turbulent air-sea exchanges of heat, moisture and momentum can be computed inside SURFEX using various bulk formulas. A first parameterization uses Charnock's (1955) formula for the roughness length and Louis's (1979) formulations for a direct computation of the exchange coefficients. Iterative computations of the air-sea surface turbulent fluxes can also be activated. In these formulations, the exchange coefficients are obtained it- eratively as a function of the wind speed vertical gradient between the sea surface and $10 \mathrm{~m}$ height, both parameters being reduced to neutral stratification conditions. First, the COARE 3.0 iterative algorithm of Fairall et al. (2003) can be used. SURFEX also includes the ECUME (Exchange Coefficients from Unified Multi-campaigns Estimates, Belamari, 2005; Belamari and Pirani, 2007) iterative parameterization, derived from multi-campaign measurements in situ (Weill et al., 2003) and covering the widest possible range of atmospheric and oceanic conditions from very light winds up to cyclones. The two latter parameterizations can include optional corrections (due to gustiness, precipitation, density effects) to the sea surface heat and momentum fluxes.

Lastly, SURFEX includes the computation of the shortwave upward component of the radiative fluxes, using either a fixed albedo value or an evolving one depending on the zenith angle (Taylor et al., 1996).

\subsection{Inland water surfaces}

There are two ways to calculate the fluxes at the air-water interface over a lake in SURFEX. The first, which is relatively simple, is based on the calculation of the roughness length from the Charnock (1955) formula. The surface turbulent fluxes are then calculated with the parameterization of Louis (1979), using a constant surface temperature of the water throughout the run. This method, although easy to implement, has the drawback of not taking the diurnal cycle of the water surface temperature into account. This approach can be justified for deep lakes (or seas and oceans) for which the thermal amplitude remains low over several hours during the daytime. However, it seems more questionable for small to medium-sized shallow lakes, where the daily temperature range can reach several degrees. A correct simulation of this type of lakes is important for high resolution NWP models.

The alternative to using this simple parameterization is to use lake models that are able to predict the evolution of the temperature structure of lakes of various depths, at different timescales. The freshwater lake model (FLake; Mironov et al., 2010) has been coupled to SURFEX. FLake is an integral (bulk) model. It is based on a two-layer parametric representation of the evolving temperature profile within the water column and on the integral energy budget for these layers. The structure of the stratified layer between the upper mixed layer and the basin bottom, the lake thermocline, is described using the concept of self-similarity (assumed shape) of the temperature-depth curve. The same concept can be used optionally to describe the temperature structure of the thermally active upper layer of bottom sediments and of the ice and snow cover. Finally, FLake also deals with snow and ice above the lake.

The model requires external parameters, the most relevant of which is the lake depth. A global database of lake depths has been developed for that purpose (Kourzeneva et al., 2012). The extinction coefficient is also important, but 
no databases are available at this stage. This parameter can be prescribed uniformly, but the possibility to use maps is already implemented. It should be noted that FLake is a shallow water model that has no representation of the hypolimnion, a third layer usually present between the thermocline and the bottom of deep lakes. Thus, a limiting value of $60 \mathrm{~m}$ should be taken for lake depth, based on the results of Perroud et al. (2009). Knowledge of sediment properties and of the optical characteristics of the water are also important, but this information is largely unavailable and prescribed values are usually adopted.

The surface fluxes can be calculated with the formulation of Louis (1979), using the surface temperature calculated by FLake, or by the original flux parameterization of FLake.

The FLake model was also incorporated as a lake parameterization module in SURFEX because it was successfully coupled with NWP models like the limited-area NWP model HIRLAM, the UK Met Office Unified Model, the COSMO-EU (Europe) configuration of the COSMO model and also with regional climate models like CLM (http://www. clm-community.eu/), RCA SMHI - from the Swedish Meteorological and Hydrological Institute, and the ECMWF Integrated Forecasting System. In addition, FLake's modular structure substantially facilitated its implementation within the SURFEX environment (Salgado and Le Moigne, 2010). Finally, the parametric approach of this two-layer model leads to a low computational cost, which is a necessary condition for its use in an operational environment. The LakeMIP intercomparison exercise (Stepanenko et al., 2010) showed that, despite its simplicity, FLake satisfactorily reproduced the water temperature profiles under various forcing conditions when compared to other one-dimensional lake models such as Simstrat (Peeters et al., 2002), LAKE (Stepanenko and Lykosov, 2005), Hostetler's model (Hostetler and Bartlein, 1990) or CLM-VRLS (Subin et al., 2012).

\section{Chemistry, dusts, sea salts}

\subsection{Gas and anthropogenic aerosol emissions}

Gas and primary aerosol emissions are extremely heterogeneous (e.g. traffic emissions depend on traffic congestion, emissions from industries are highly variable, etc.) and can hardly be modelled. These emission are prescribed in SURFEX using emission inventories: maps of potential emissions for each chemical species for several sectors (traffic, industry, refining, agriculture, etc.) and are modulated by typical (or observed if available) time information (usually depending on time of day and week/weekend or holiday days). On the other hand, the biogenic volatile organic compound (BVOC) emissions by vegetation depend on meteorological conditions and can be directly parameterized (Solmon et al., 2004; Guenther et al., 1995). These biogenic emissions can either be prescribed or simulated dynamically in SURFEX.
For anthropogenic aerosols, the mass flux is converted into two log-normal modes for the representation of Aitken mode and accumulation mode (Tulet et al., 2005).

\subsection{Dust emission over deserts}

Dust is an important aerosol with annual global emissions ranging from 1000 to $3000 \mathrm{Tg} \mathrm{yr}^{-1}$ and average global load around 10-30 Tg (Zender et al., 2004). Dust is mobilized from dry desert surfaces when the wind friction velocity reaches a threshold value of approximately $0.2 \mathrm{~m} \mathrm{~s}^{-1}$.

Dust is mobilized by two related processes called saltation and sandblasting. Saltation is the horizontal movement of soil grains in a turbulent near-surface layer. Sandblasting is the release of fine dust when the saltating grains hit the surface. Several papers document these two processes. Marticorena and Bergametti (1995) and references therein describe the physics of saltation, and Shao et al. (1993) describe the physics of sandblasting. The dust fluxes are calculated using the Dust Entrainment and Deposition (DEAD) model (Zender et al., 2004) introduced into SURFEX by Grini et al. (2006) and recently improved by Mokhtari et al. (2012) to better account for the soil aggregate distribution.

The dust particles follow a tri-modal distribution that is compatible with the log-normal distribution of aerosols (Crumeyrolle et al., 2011).

\subsection{Sea salt}

Sea salt aerosols are produced as films and jet droplets through disruption of the sea surface by bubbles entrained in the water by breaking waves (Blanchard, 1983) and, at wind speeds exceeding about $9 \mathrm{~m} \mathrm{~s}^{-1}$, through direct disruption of the wave tops (spume droplets) (Monahan et al., 1986). Sea salt emission is parameterized using the formulation of Vignati et al. (2001) (effective source function) or a lookup table defined by Schulz et al. (2004). Vignati et al. (2001) provide a formulation of the particle emission flux that depends on the wind speed at $10 \mathrm{~m}$ above the sea surface. Sea salt particles follow a tri-modal distribution, in a manner similar to dust.

\subsection{Dry deposition of chemical species and aerosols}

Dry deposition refers to the removal of gases from the atmosphere by turbulent transfer and uptake at the surface. This process enables some chemically reactive gases to be efficiently removed from the atmosphere. Dry deposition is usually parameterized through a deposition velocity $v_{\mathrm{d}}$, defined by $v_{\mathrm{d}}=V-V F_{\mathrm{c}} / c(z)$, where $F_{\mathrm{c}}$ is the flux of the compound in question $\left(F_{\mathrm{c}}\right.$ is assumed constant over the range of heights considered) and $c(z)$ is the concentration at height $z$ (molecules $\left.\mathrm{cm}^{-3}\right) \cdot v_{\mathrm{d}}$ depends on many variables such as wind speed, temperature, radiation, chemical properties of species (Henry constant, biological reactivity and molecular 
mass) and surface conditions. It is commonly described through a resistance analogy (e.g. Wesely and Hicks, 1977).

Note that, in cities, the total surface available for exchanges (i.e. including walls) is taken into account. Above vegetation, chemical species interact in more complex ways. Dry deposition velocities are computed from theoretical considerations based, for instance, on solubility and equilibrium: calculations in combination with simulation of vegetation specific processes, such as accumulation, transfer process through stomata, mesophyll, cuticles, etc. (Baldocchi et al., 1987; Wesely, 1989). In SURFEX, the deposition of each chemical species is computed following Weseley (1989) and Seinfeld and Pandis (1997) and the code is split for all tiles and patches (Tulet et al., 2003).

For dry deposition of aerosols (dust, sea salt and anthropogenic aerosols) a sedimentation term is added (Seinfeld and Pandis, 1997). The formulation of the sedimentation velocity has been re-written by Tulet et al. (2005) for use by a multi-moment log-normal aerosol model.

\section{Coupling strategies}

\subsection{Exchanges with the atmosphere}

In SURFEX, the exchanges between the surface and the atmosphere are modelled using a standardized interface (Best et al., 2004) that proposes a generalized coupling method between the atmosphere and the surface (Fig. 3). During a model time step, each surface tile and patch receives the upper air temperature, specific humidity, horizontal wind components, pressure, total precipitation, long-wave radiation, short-wave direct and diffuse radiation fluxes (the atmospheric spectral bands are aggregated into three bands: ultraviolet, visible and near infrared) and possibly concentrations of chemical species and dust. In return, SURFEX computes averaged fluxes for momentum, sensible and latent heat, and possibly chemical species and dust fluxes, and then sends these quantities back to the atmosphere with the addition of radiative terms like surface temperature, surface direct and diffuse albedo (for each wavelength) and also surface emissivity. This information is then used as the lower boundary condition for atmospheric radiation and turbulence schemes.

\subsubsection{Implicit/explicit coupling}

SURFEX can be coupled to numerical atmospheric models in order to provide them with the surface boundary condition. Climate models use long time steps (up to $30 \mathrm{mn}$ ) that need to implement fully implicit coupling between the atmosphere and the surface in order to avoid numerical oscillations. Best et al. (2004) proposed a simple interface to allow implicit coupling between the atmosphere and a tiled surface, which has been implemented in SURFEX. The surface scheme computations for the fluxes are just slightly modified to take account of an additional coefficient describing the relationship between the surface flux (e.g. heat flux) and the variable it will modify (e.g. temperature).

The coupling between the atmosphere and ISBA is implicit for all variables. The coupling for other schemes is only implicit for the wind (but there is no evidence so far of any oscillation with these schemes for other variables, due to an internal implicit evolution for the variables in the schemes).

\subsubsection{Atmospheric surface-boundary-layer (SBL)}

To improve the description of the physical coupling between the air and the surface, a one-dimensional surface boundary layer has been implemented in SURFEX in order to account for the vertical gradients of the variables of the lowest part of the atmosphere (Masson and Seity, 2009; Fig. 5). The main objectives of the use of an SBL in SURFEX are to

1. Better simulate the profile of wind, temperature, humidity and turbulence between the surface and the forcing level (usually, this is done diagnostically using MoninObuhkov similarity laws). This improves the forecast of near-surface air temperature at night when stability is strong (Masson and Seity, 2009).

2. Take account of the effect of vegetation or urban canopies on the in-canopy air. For example, it allows the micro-climate between buildings to be simulated in TEB, or the wind profile to be modified by the trees. For wind, it uses a drag force of the form $\mathrm{d} u / \mathrm{d} t=-C_{\mathrm{d}}(z) u$, where $u$ is the wind speed and where the drag coefficient depends on building density or the leaf area index of trees. Heat and water fluxes directly influence the atmospheric surface layer at the height where they are released.

3. Better force the surface model, using air characteristics at the corresponding level (e.g. in TEB, near-road air temperature is used for roads, while mid-height canyon air temperature is used for walls).

One SBL profile is implemented for each of the four main tiles. First layers are usually at $50 \mathrm{~cm}, 2 \mathrm{~m}, 4 \mathrm{~m}, 7 \mathrm{~m}$, and $10 \mathrm{~m}$ above the surface, but can be modified. Two metre temperature and humidity, and $10 \mathrm{~m}$ wind, are prognostically computed by the SBL scheme for each tile. Note that the SBL scheme is implicitly coupled with the surface schemes, but not with the atmosphere, which may cause instabilities for long time steps. Hence, the SBL is not used for climate runs.

\subsubsection{Orographic friction}

Subgrid-scale orography is well known for its friction effect on the atmosphere. Observations (Grant and Mason, 1990; Kustas and Brutsaert, 1986) have shown that small hills tend to produce a logarithmic wind profile above themselves, typical of a large roughness length. Therefore, roughness length 
without SBL model

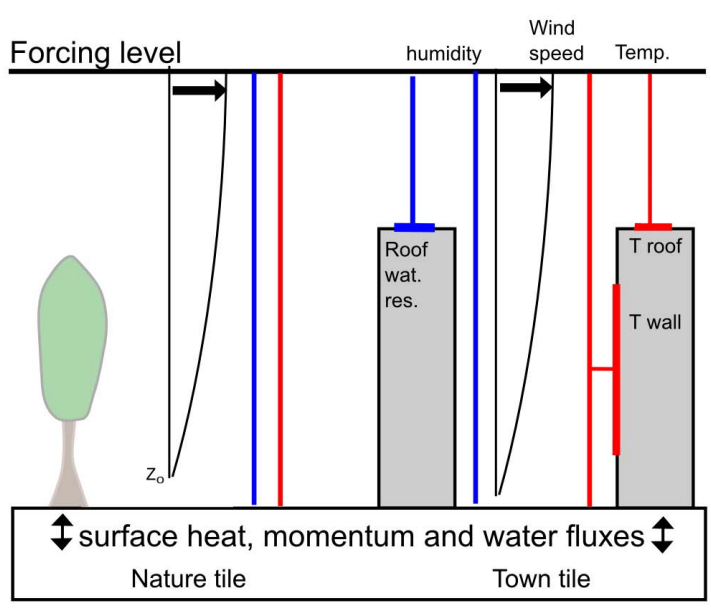

with SBL model

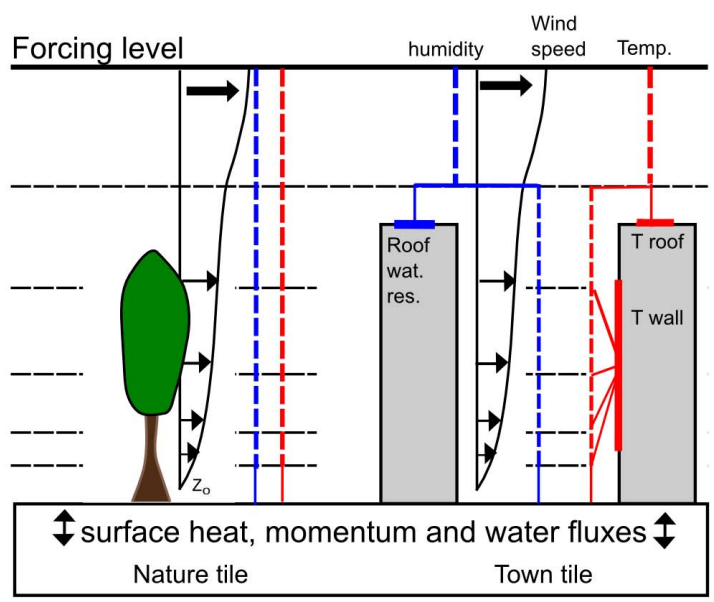

Fig. 5. Schematic view of the coupling between the surface (ISBA and TEB) and the atmosphere without the SBL model (a) and with the SBL model (b). In the latter case, a drag force is applied in the Nature and Town tiles for the wind. The temperature profile in the SBL model is influenced by the road, wall and roof temperatures. The humidity profile is influenced by the road and roof humidities.

approaches have been widely used, even for large mountains (e.g. Wood and Mason, 1993; Georgelin et al., 1994). Recent works (Beljaars et al., 2004) have preferred to parameterize orographic drag not only at the surface but throughout a certain height above it (adding a drag force directly in the wind equations of the lowest layers of atmospheric models). Thanks to the SBL scheme included in SURFEX, the latter option can now be used in the surface scheme itself.

The friction can be computed by a roughness length or directional roughness length (mostly depending on the main subgrid-valley directions, Georgelin et al., 1994), or by using Beljaars et al.'s (2004) approach, in which case an additional SBL scheme with only wind and turbulence needs to be added. Orographic friction is caused by obstacles of a much larger horizontal scale than trees or even buildings. Therefore, these frictions are computed separately (assuming that the processes are independent of each other): the friction of natural land surface, towns, water and sea surface are averaged, and then only orographic friction is added, in the following way: $\left(u_{*}(\text { total })^{2}=u_{*}(\text { surface })^{2}+u_{*}(\text { orography })^{2}\right)$. This also has the advantage that low-level air temperature and humidity are consistent with the characteristics of the land cover below (including its own roughness).

\subsection{Coupling with hydrology}

The main function of river routing models (RRMs) is to convert runoff simulated by LSMs into river discharge. The routing of runoff estimates from LSMs is important to model river flow from large river basins and to estimate freshwater inflow into the oceans. The coupling of SURFEX with RRMs appears to be a powerful tool for understanding the regional and global water cycles (Habets et al., 1999b; Decharme and
Douville, 2007; Alkama et al., 2010), predicting streamflow (Habets et al., 2004; Quintana Seguí et al., 2009; Thirel et al., 2010), and improving model parameterizations (Boone et al., 2004; Decharme et al., 2006, 2010, 2011; Decharme and Douville, 2006a).

At catchment scale, ISBA can be coupled with the hydrodynamical TOPODYN model (Pellarin et al., 2002). Up to now, this coupling has been used to simulate flash-flood events, such as those that occur over Mediterranean basins of France (Vincendon et al., 2010; Bouilloud et al., 2010). The northwestern Mediterranean area is prone to severe rainy events, especially in autumn. High cumulative amounts of precipitation fall on small to medium catchments, which are characterised by steep slopes and short hydrological response times. Mediterranean flash-floods are thus essentially driven by Dunne runoff over saturated areas. According to the TOPMODEL approach (Beven and Kirkby, 1979), the TOPODYN model is based on the lateral soil water transfer following the topographical information but also takes the spatial variability of rainfall over a given catchment into account.

The interest of the ISBA-TOPODYN coupling (Vincendon et al., 2010; Bouilloud et al., 2010) is to take advantage of the topography driven processes managed by TOPODIN at small scale to provide a subscale spatial distribution of soil moisture according to the topography (wetter soil in the flat bottoms of valleys than on the steep slopes). This leads to significant differences in the spatial distribution of the soil moisture at surface scheme scale, which then impact the estimation of the soil water fluxes. Vincendon et al. (2010) showed that ISBA-TOPODYN was efficient to simulate French Mediterranean flash-floods using hourly observed rainfall data such as radar precipitation estimates. For 
this application, spatial resolutions of $1 \mathrm{~km}$ for ISBA and $50 \mathrm{~m}$ for TOPODYN were used.

At the regional scale, SURFEX will soon have replaced an older version of ISBA within the Météo-France hydrometeorological system SAFRAN-ISBA-MODCOU (SIM, Habets et al., 2008) over France. In this suite, SURFEX is fed by a mesoscale meteorological analysis (SAFRAN, Quintana Seguí et al., 2008) and feeds a distributed hydrological model over France (MODCOU). Decharme and Douville (2006a) have also shown that this system is an interesting tool to evaluate new model versions such as the set of sub-grid parameterizations described in Sect. 4.1.

Finally, SURFEX is coupled with the global TRIP RRMs in order to study the continental part of the global hydrological cycle (Decharme and Douville, 2007; Alkama et al., 2010) and/or to close the hydrological budget in the CNRMGAME climate model (Voldoire et al., 2012). The original TRIP RRM was developed by Oki and Sud (1998) at the University of Tokyo. It is used at Météo-France to convert the simulated runoff into river discharge using a global river channel network at $1^{\circ}$ or $0.5^{\circ}$ resolution. TRIP considers a surface river reservoir, a simple one-dimensional groundwater reservoir and a variable stream flow velocity (Decharme et al., 2010). Decharme et al. (2008, 2012) developed interactive coupling between SURFEX and TRIP to simulate seasonal flood events and to represent their impact on the continental evapotranspiration and energy budget for large-scale applications and climate modelling. The flood dynamics is described by including a prognostic flood reservoir in the daily coupling between ISBA and TRIP. This reservoir is full when the water level exceeds the bank-full limit and viceversa. Its dimension evolves dynamically according to the flood water mass and the sub-grid topography in a given gridcell. The reservoir interacts with surrounding soil through infiltration and with the overlying atmosphere through precipitation interception and free water surface evaporation.

\section{Data assimilation}

The initialization of the prognostic variables of the surface schemes is an important issue for short- and medium-range weather forecasts, particularly for quantities that evolve more slowly than atmospheric timescales (e.g. deep soil moisture and temperature, snow reservoir). Without a dedicated initialization, spurious feedbacks can take place between the atmosphere and the surface, driving the soil variables into unrealistic states (Viterbo and Courtier, 1995). The best initialization is obtained from data assimilation systems that merge observations and model short-range forecasts optimally. Monitoring of land surface fluxes can also be significantly improved when observations are assimilated in surface schemes (e.g. Reichle et al., 2007).

\subsection{Optimal interpolation}

A first data assimilation system based on local optimum interpolation (OI), originally proposed by Mahfouf (1991) and adapted to operational numerical weather prediction systems at Météo-France (Giard and Bazile, 2000), ECMWF (Douville et al., 2000) and CMC (Bélair et al., 2003), is available in SURFEX for the assimilation of screen-level observations from the surface network (e.g. SYNOP and METAR reports). The OI scheme allows soil moisture contents and soil temperatures to be corrected through the knowledge of short-range forecasts errors in temperature and relative humidity at $2 \mathrm{~m}$. Analytical OI coefficients have been derived from MonteCarlo single column experiments in clear-sky situations and need to be reduced when near-surface atmospheric errors are not informative about errors in the soil variables.

\subsection{Extended Kalman filter (EKF)}

Although still used by a number of numerical weather services, the OI scheme has a number of known weaknesses, such as its lack of flexibility regarding the observation types to be assimilated (only screen-level temperature and relative humidity) and the model variables to be initialized (only the two soil reservoirs of the ISBA version based on the force-restore method). For these reasons, a new surface assimilation scheme based on the EKF has been developed within SURFEX. This scheme compares favourably with the OI scheme for the assimilation of screen-level observations (Mahfouf et al., 2009). The "offline" version of SURFEX forced by atmospheric parameters above screen level (around $20 \mathrm{~m}$ in the surface boundary layer) can efficiently compute (reduced numerical cost) the Jacobian matrix of the observation operator. Also, the capability of the EKF to assimilate satellite-derived superficial soil moisture products from the radiometer AMSR-E/Aqua has been demonstrated (Draper et al., 2009). The combined assimilation of satellite-derived soil moisture and screen-level observations with the EKF was examined by Draper et al. (2011b). A simplified version of the SURFEX EKF using analytical Jacobians of the ISBA scheme has also been developed in order to examine the impact of satellite-derived soil moisture from the scatterometer ASCAT on numerical weather predictions (Mahfouf, 2010). Recently, Mahfouf and Bliznak (2011) proposed a method to efficiently combine information coming from precipitation analyses (radars or raingauges) and from screen-level measurements within the EKF.

Regarding land surface monitoring, the EKF has been used to assimilate the LAI and superficial soil moisture measurements jointly in the ISBA-Ags version, where biomass reservoirs are prognostic variables (Barbu et al., 2011), both at local scale using in situ measurements from the SMOSREX field experiment and over France as a whole using satellite-derived products (ASCAT derived soil moisture, CYCLOPES and SPOT/VGT LAI product). The use 
of the ISBA-Ags model has allowed the Jacobians of a new variable, the vegetation biomass, to be examined (Rüdiger et al., 2010), and also the formulation of the EKF to be extended to the availability of 12 patches in a grid box (i.e. different surface and soil prognostic variables for each patch) and one single "grid-averaged" observation. Draper et al. (2011a) showed that the assimilation of the satellitederived ASCAT soil moisture improve runoff and river discharge simulations when assimilated in the hydrometeorological model SIM (Habets et al., 2008) using the SURFEX EKF data assimilation system. It must be noted that some products such as LAI and soil moisture are biased and require a pre-processing, as SURFEX assumes that observations are unbiased. For the present applications, the biases are corrected using a "CDF (cumulative distribution function) matching technique" (Reichle and Koster, 2004).

Finally, studies are currently under way to improve the specification of the covariance matrix of background errors in the EKF through a better description of model errors. Using a model error term derived from an ensemble of shortrange forecasts of precipitation, which is cycled through the filter, generates realistic spatial variability patterns in the background errors.

\section{Model applications and evaluations}

Most pre-existing scientific models (e.g. ISBA and TEB) were used and validated in various configurations before the building of SURFEX, both in offline mode and coupled with the atmosphere. As an example, ISBA (Noilhan and Planton, 1989) has been regularly improved over more than $20 \mathrm{yr}$. The scientific work of improvement and validation of the physics continued during the transition from the pre-existing codes to SURFEX while, from a technical point of view, the progressive replacement of the surface components implied significant technical work. In most cases, the introduction of SURFEX into the applications (in particular atmospheric models) allowed an improvement of the surface parameterization and scores, drawing benefit from the use of an up to date externalized surface scheme.

It is beyond the scope of this paper to provide a comprehensive review of all the validations of the sub-models included in SURFEX. In the first sub-section, the applications and validations in offline mode (either local or distributed) will be reviewed rapidly. Then, the impact of the introduction of SURFEX in atmospheric models will be shown.

\subsection{Applications in offline mode}

\subsubsection{ISBA}

The original version of ISBA (Noilhan and Planton, 1989) and further improved versions have been extensively validated against measurements at the local scale and partici- pated in many intercomparison projects that have stimulated improvements in the model:

- PILPS (Henderson-Sellers et al., 1993): ISBA application to the Cabaw (Chen et al., 1997), and Arkansas River (Wood et al., 1998; Liang et al., 1998; Lohmann et al., 1998) datasets, leading to improved subgrid hydrology. The simulation of a Scandinavian basin (Habets et al., 2003) was the first application of the multilayer soil option of ISBA for hydrology and validated the cold processes in the soil. Valdaï (Slater et al., 2001 and Luo et al., 2003) was the occasion to further validate the snow and cold processes in the soil.

- GSWP (Dirmeyer et al., 1999, 2006): validation and intercomparison of hydrological parameterization at the global scale, including uncertainties associated with the forcing data (Decharme and Douville, 2006b).

- Rhone-Aggreg (Boone et al., 2004): testbed for scale changes, subgrid hydrology and the use of the multilayer snow model (ISBA-ES).

- SnowMIP (Etchevers et al., 2003; Rutter et al., 2009): importance of the representation of albedo in snowpack models, simulation of the liquid water content in the snow for an accurate prediction of snowmelt, importance of the interaction between snow and vegetation for an accurate simulation of the snow cover in forests.

More recently, SURFEX has been applied in Africa within ALMIP (AMMA Land Surface Models Intercomparison Project; Boone et al., 2009), a validation of the surface energy budget over France using different sources for the incoming solar radiation, including METEOSAT satellite estimates, has been undertaken by Carrer et al. (2012) and the multilayer soil scheme (Boone et al., 2000) has been extensively validated by Decharme et al. (2011) at the SMOSREX (Surface Monitoring Of Soil Reservoir Experiment) site in the south west of France.

The representation of cryospheric processes in the soil has been validated by Boone (2000) on a well-instrumented site in Ilinois (USA), by Bazile (1999) in the context of numerical weather prediction, and by Habets et al. (2003) over a Scandinavian basin. Concerning snow processes, the focus in recent months has been on the validation of Crocus, with a new SURFEX version completely rewritten and coupled with ISBA (Vionnet et al., 2012). Crocus has been evaluated at the point scale at the Col de Porte site (1325 m a.s.l., French Alps) using in situ driving and evaluation data spanning a time period of $18 \mathrm{yr}$ (Vionnet et al., 2012), at distributed scale using ERA-Interim (Dee et al., 2011) meteorological forcing and ground-surface snow depth, snow water equivalent and ground temperature evaluation data (Brun et al., 2013), and under Antarctic conditions at Dome $\mathrm{C}$ in both offline and online mode (Brun et al., 2011). 
Considerable efforts have gone into the validation of the advanced parameterization of vegetation processes, including carbon variables. Gibelin et al. (2006) have shown that ISBA-A-gs simulates realistic LAI values at the global scale under various environmental conditions. Noilhan et al. (2011) have shown the added value of both the tiling and Ags approaches on the quality of regional atmospheric simulations. Brut et al. (2009) and Lafont et al. (2012) have shown that, over France, ISBA-A-gs efficiently captures the LAI interannual variability as observed from space by satellite sensors. Also, this capability applies to the above-ground biomass of cereals and grasslands and can be verified using agricultural statistics (Calvet et al., 2012). On the other hand, the seasonal variability of the simulated LAI may present shortcomings (Brut et al., 2009; Lafont et al., 2012). In particular, a delay in the leaf onset is observed. No specific phenology model is used by ISBA-A-gs as vegetation growth and senescence are entirely driven by photosynthesis. In consequence, the simulated LAI is sensitive to imperfections in the model parameterization and in the atmospheric forcing used to drive the simulation. The simulated LAI is flexible and prescribing cuts at given dates (Calvet and Soussana, 2001) or when LAI has reached a predefined threshold (Calvet et al., 2012) is not difficult. This property can be used to assimilate LAI observations into the model (Sabater et al., 2008; Albergel et al., 2010b; Rüdiger et al., 2010; Barbu et al., 2011). Also, provided that the impact of the nitrogen limitation on SLA is accounted for (Calvet et al., 2008), the interactive vegetation simulations of ISBA-A-gs can be used to represent the uncertainties on the plant response to decadalto-centennial changes in the atmospheric $\mathrm{CO}_{2}$ concentration (Queguiner et al., 2011).

The coupled ISBA-TRIP model including a flood scheme has been validated at the global (Decharme et al., 2008; Decharme et al., 2012) and regional scales (Pedinotti et al., 2012). This system simulated a reasonable distribution of the global floodplains compared to satellite-derived estimates. In addition, the river discharges have generally been well reproduced using this flood scheme over many basins of the world (Fig. 6). The efficiency scores of the version with a flood scheme are increased (increase higher than 0.05) over $50 \%$ of the 122 gauging stations and only reduced (decrease lower -0.05 ) for 5 stations. Considering only stations with a positive efficiencies ( 68 for the new scheme against 61 for the control run), the mean score is 0.57 for the new scheme against 0.54 for the control run. The mean RMSE over all station is also reduced from 0.64 to $0.56 \mathrm{~mm} \mathrm{day}^{-1}$. Two mechanisms mainly explain this positive impact: an increase in evapotranspiration, which limits the annual discharge overestimation found when flooding is not taken into account, and a smoothed river peak flow when the floodplain storage is significant.

\subsubsection{TEB}

TEB has been intensively validated against in situ measurements, for various types of cities and urbanization, under various climates: from wintertime Montreal (Lemonsu et al., 2010; Leroyer et al., 2010) to Ouagadougou in the African Sahel (Offerle et al., 2005a). The other sites where TEB has been validated are old city centres, Marseilles, Toulouse, Basel, Lodz, Mexico City (Masson et al., 2002, 2008; Lemonsu et al., 2004; Offerle et al., 2005b; Pigeon et al., 2008; Hamdi and Masson, 2008), light-industry sites (Masson et al., 2002), and suburban areas of Oklahoma city (Lemonsu et al., 2009), Melbourne and Nantes (Grimmond et al., 2010, 2011; Lemonsu et al., 2007).

\subsection{Applications in coupled mode with an atmospheric model}

In recent years, SURFEX has been progressively implemented and validated in various atmospheric models used either for process studies or for operational numerical weather prediction and climate runs. The new convective-scale model AROME (Seity et al., 2011; Brousseau et al., 2011), with a $2.5 \mathrm{~km}$ grid, has used SURFEX since the beginning, in 2008 . SURFEX was introduced into the ALADIN model $(7.5 \mathrm{~km}$ grid) in September 2010 (French Antilles/Guyana, French Polynesia and New Caledonia). Réunion Island has been using SURFEX since 2011. At this date, an optimal interpolation (OI) assimilation for soil moisture was implemented in all the numerical suites. SURFEX has also been introduced into version 5 of the general circulation model CNRM-CM5 (Voldoire et al., 2012). An interactive model of desert dust emission within ALADIN has been tested (Mokhtari et al., 2012). This sub-section presents a selection of applications and validations of SURFEX in coupled mode.

\subsubsection{Evaluation of SURFEX within the ALADIN/France meteorological model}

In ALADIN, a maximum of three tiles (sea, nature and lakes) are activated. The town tile is currently not activated in this configuration owing to some numerical instabilities which occured when TEB used without wind implicitation was coupled to the atmosphere using long time steps. For now, town surfaces are simply replaced by the rock class within the nature tile. A three-layer force-restore version of ISBA is used (instead of the former two-layer version) with a onelayer snow scheme. The ECUME parameterization of sea surface fluxes is used over seas. Over continents, the prognostic SBL is used. Physiographic data have also been improved (GTOPO30, ECOCLIMAP1, and FAO maps for soil texture). 

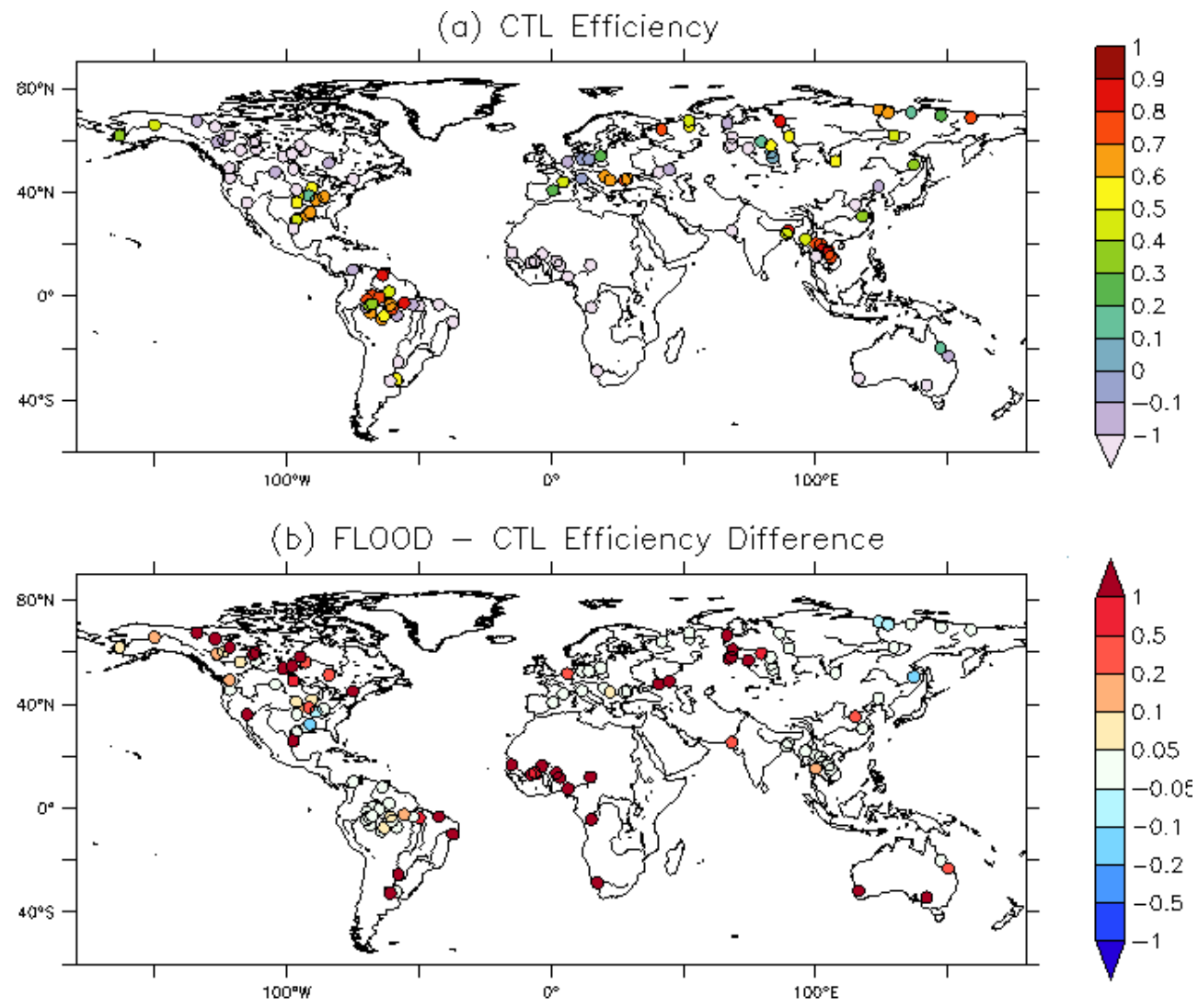

Fig. 6. Validation of the ISBA/TRIP simulation with in situ discharge measurements using the 1986-2006 period. (a) Efficiency of the original simulation (without flood parameterization). (b) Variation of the efficiency when the flood coupling between ISBA and TRIP is activated.

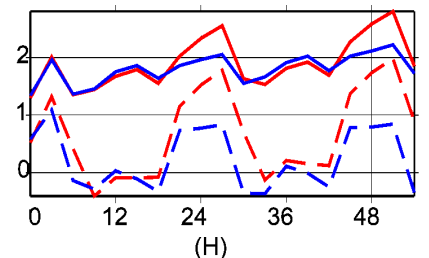

$\mathrm{T} 2 \mathrm{~m}(\mathrm{~K})$

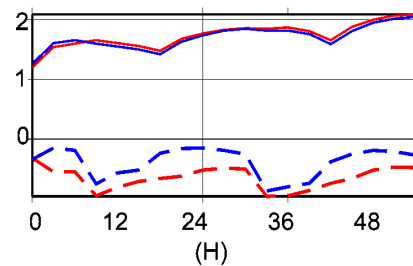

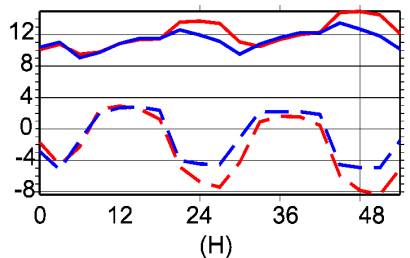

$\mathrm{Hu} 2 \mathrm{~m}(\%)$

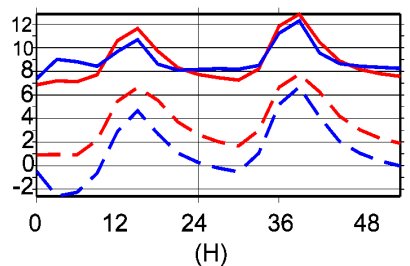

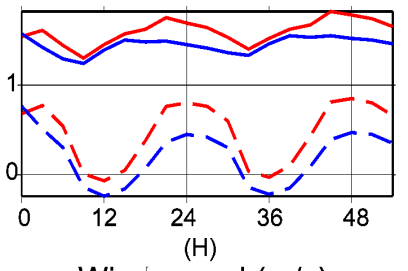

Wind speed $(\mathrm{m} / \mathrm{s})$

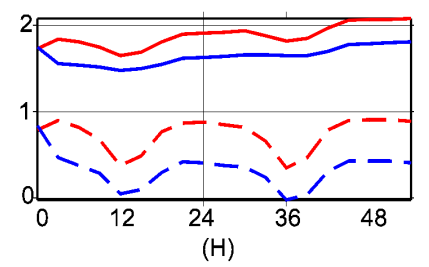

Fig. 7. Evaluation of SURFEX within the ALADIN/France configuration for a summer period (June-September 2010) (top) and a winter period (December 2010-March 2011) (bottom). Biases (dashed lines) and rms (continuous lines) as a function of the forecast lead time are presented for the ALADIN without SURFEX (in red) and with SURFEX (in blue). Left: $2 \mathrm{~m}$ temperature (K), centre: $2 \mathrm{~m}$ humidity (\%), right: $10 \mathrm{~m}$ wind speed $\left(\mathrm{ms}^{-1}\right)$.

Extensive tests contributing to the definition of the operational version described above were conducted to assess ALADIN's performance with and without SURFEX. The forecasts were compared to screen-level observations. The intro- duction of SURFEX was neutral on surface pressure, precipitation, total cloudiness and $10 \mathrm{~m}$ wind direction (not shown) but improved the scores for $2 \mathrm{~m}$ temperature, humidity and wind speed (Fig. 7). 

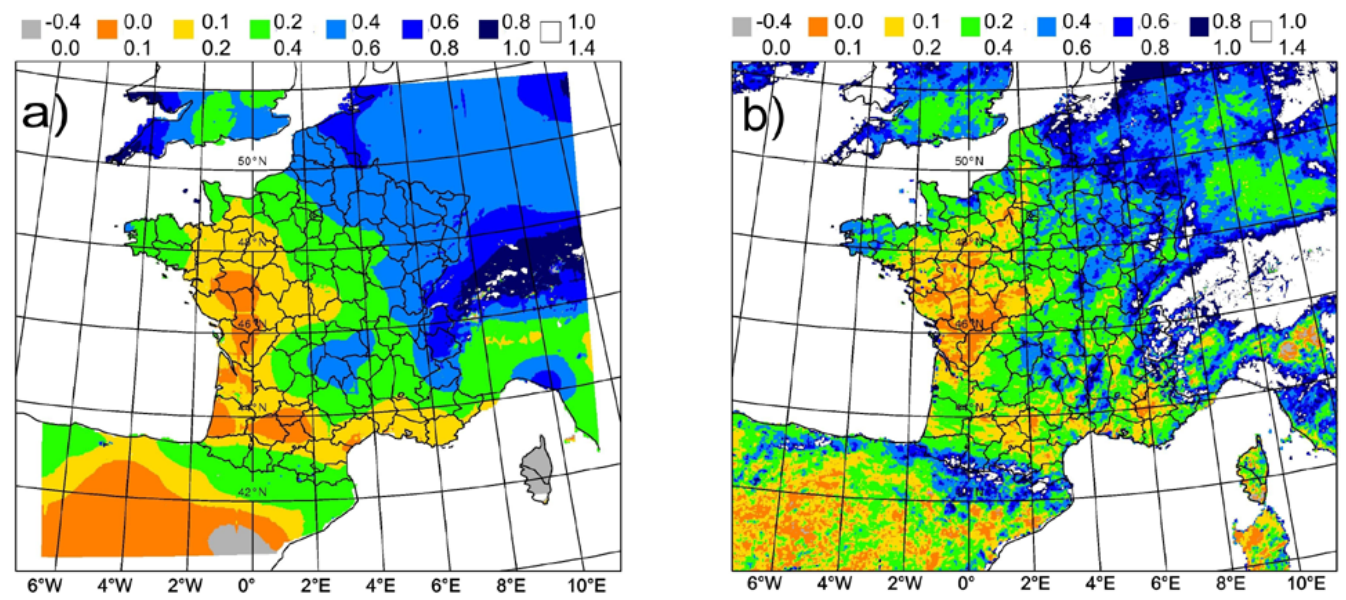

Fig. 8. Soil wetness index (negative values are associated with very dry soils; values larger than one indicate moist soils evaporating at maximum rate) on 1 October 2010. (a) Operational AROME suite (soil moisture field interpolated from the one produced for the globalscale model ARPEGE). (b) Experimental AROME suite (having its own surface analysis system).

\subsubsection{Impact of the introduction of a fine scale soil moisture assimilation into AROME}

The assimilation of screen-level temperature and humidity described in Sect. 7.1 was implemented in the AROME model in November 2010. This model has a dedicated atmospheric data assimilation system providing optimal corrections every $3 \mathrm{~h}$ to short-range forecasts using specific mesoscale observations such as radar data. These corrections lead to an improved state of the atmosphere (analysis) from which new forecasts can be established. The quality of fine scale forecasts also depends upon the land surface state (soil temperatures and moisture contents) since this strongly influences water and energy exchanges with the atmosphere. Figure 8 shows the soil wetness index produced on 1 October 2010 by the operational AROME suite (interpolation from the ARPEGE model) and by the experimental AROME suite (having its own surface analysis). Most dry and wet regions in the domain are similar between the two maps. However, the interest of correcting AROME forecasts is clear in the better resolution of small scale features, particularly over mountainous regions: the dryer soil of the Alsace plain (in the northeast of France) is clearly differentiated from the wetter mountain ranges in the vicinity (Vosges and Black Forest). The introduction of a SURFEX analysis coherent with the SURFEX configuration of the land surface scheme of the model systematically improved the surface variables, in particular precipitation. Figure 9 shows that the assimilation reduced the frequency bias of the model and improved the Heidke Skill score for almost all precipitation classes over a three-week test period.

\subsubsection{Validation of SURFEX within the global climate model CNRM-CM}

SURFEX was introduced in the general circulation model CNRM-CM5.1, developed jointly by CNRM-GAME and CERFACS (Centre Européen de Recherche et de Formation avancée en Calcul Scientifique) for the phase 5 of CMIP. The main improvements since the previous version (CNRMCM3) are the following: increase in resolution, revised dynamical core, new radiation scheme with improved treatment of aerosols, new ocean model, and introduction of SURFEX. These developments generally led to a more realistic representation of the mean recent climate and to a reduction of climate drifts. The changes in the model and basic evaluations are described in detail by Voldoire et al. (2012). Between the two model versions, the surface physics has only evolved slightly but the introduction of SURFEX will allow stateof-the-art surface parameterizations to be activated in future versions. In CNRM-CM5.1, the main improvements resulting from the SURFEX implementation were the use of the ECUME parameterization for air-sea fluxes, the soil freezing parameterization (Boone et al., 2000) and tuning of the snow scheme. Figure 10 shows the performance of CNRMCM3 and CNRM-CM5 in simulating the sea surface temperature (resp. near-surface temperature) over oceans (resp. continents), compared to the HadiSST database (resp. CRU2.1 database). The mean bias and the rms error are significantly reduced in CNRM-CM5.1 when compared to CNRM-CM3. The main improvement over continents is the reduction of strong warm biases over high latitudes in winter, attributed to the freezing parameterization. The ECUME parameterization is also shown to greatly improve wind intensities in the mid-latitude storm tracks of the southern hemisphere and therefore the sea surface pressure around the Antarctic. On 

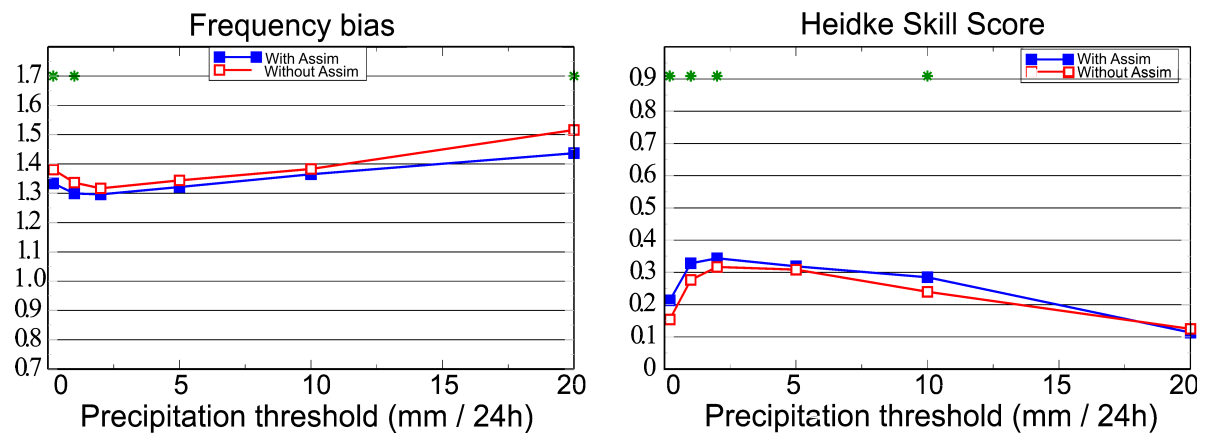

Fig. 9. Twenty-four hour accumulated precipitation forecast scores (Bias and Heidke Skill score) obtained with (blue curves) and without (red curves) soil analysis by the AROME model over a three week period (21 April 2010-15 May 2011). A green star indicates that the score difference is significant with a $90 \%$ confidence level.
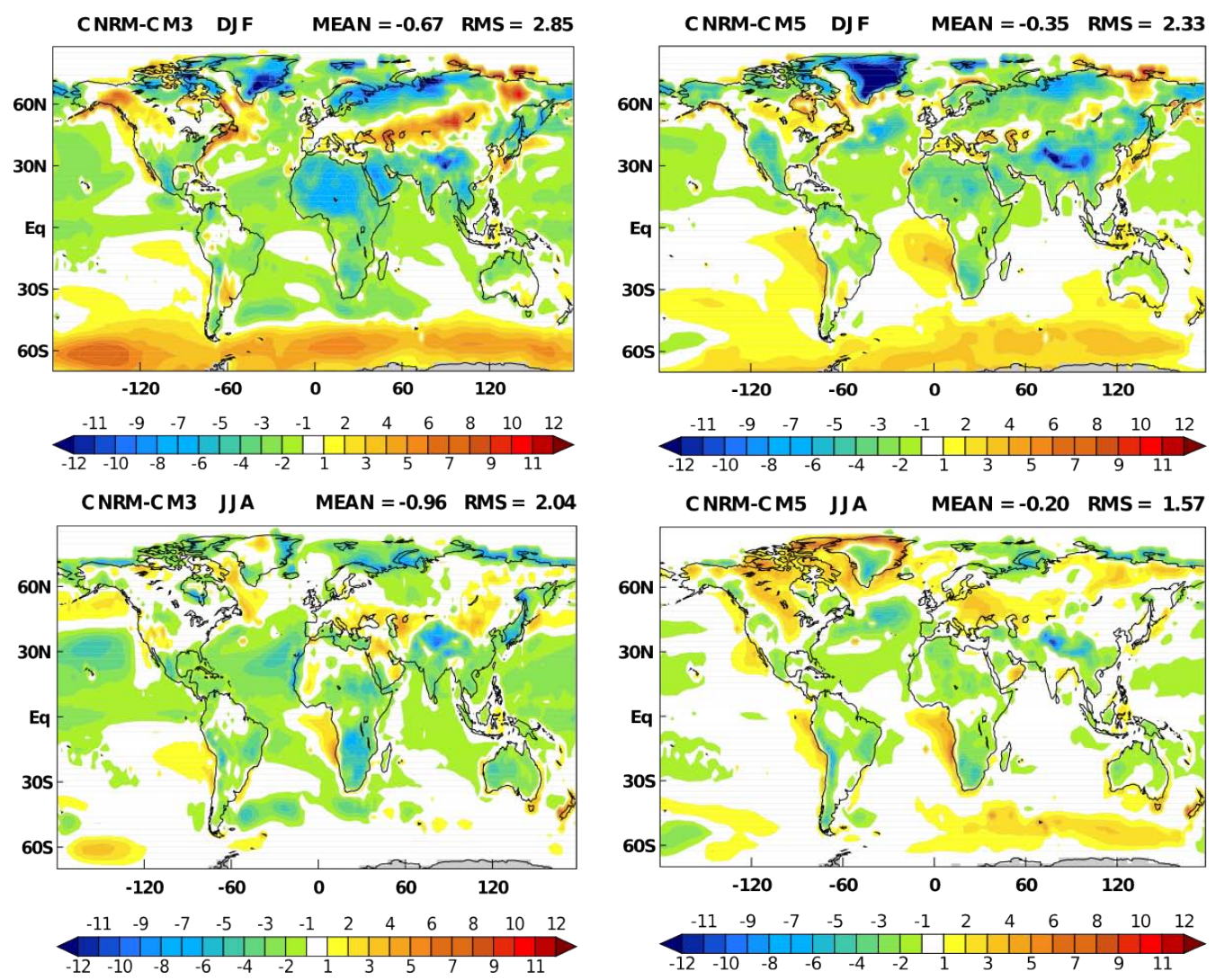

Fig. 10. Near-surface temperature over continents and sea surface temperature over oceans (K) averaged over 1970-1999: (left) CNRM-CM3 simulations minus 1970-1999 CRU2.1 over continents and CNRM-CM3 simulations minus 1970-1999 HadiSST over oceans, (top) winter, (bottom) summer, and (right) same for the CNRM-CM5.1 runs. The CNRM-CM5 runs are averaged over an ensemble of 10 members.

the other hand, a positive bias appears in summer over Eastern Europe and most of North America. This warm bias results from positive feedback triggered by a deficit in cloud cover that favours spring evaporation and thus leads to excessive summer drying that further reduces the cloud cover.

\subsubsection{Interactive modelling of desert dust emission}

The last example of the use of SURFEX illustrates the interest of the online coupling between surface models and regional models for the simulation of desert dust emissions. Figure 11 shows the mean annual emissions of desert dust calculated by the ALADIN model coupled to SURFEX to simulate desert dust emissions and deposition (Mokhtari et 


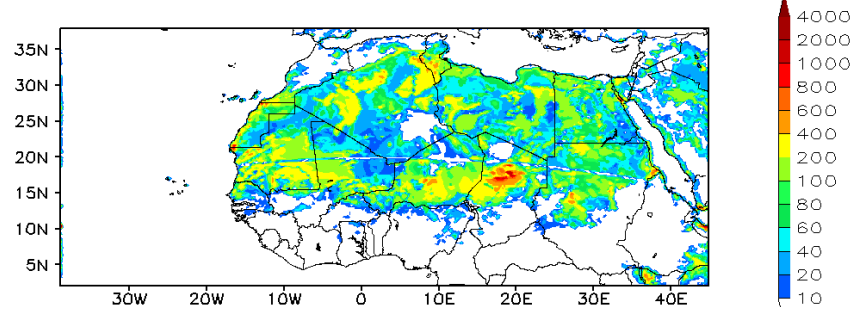

Fig. 11. Annual mean of the aerosol dust emission (in $\mathrm{g} \mathrm{m}^{-2}$ ) over West Africa, simulated by ALADIN-SURFEX between 2006 and 2011.

al., 2012). In this case, the contribution of this type of modelling is that all processes of desert dust emission are taken into account (convective turbulence, storms). This is a breakthrough compared to previous studies carried out with climate models that did not have the capacity to represent all the atmospheric processes, particularly those at small-scale or those provided by satellite observations, which were limited by their return time and by the horizontal or intrinsic resolution of their sensors.

\section{Conclusions}

The primary purpose of this paper was to provide a detailed description of the scientific and technical aspects of the externalized surface platform SURFEX. The building of SURFEX, its validation and the coupling to the atmospheric model and existing databases was a broad community effort and constitutes a significant advance relative to the preexisting individual models such as ISBA or TEB and the surface components of the atmospheric models.

One originality of SURFEX is that it covers all surface types (natural surfaces, town, inland water and oceans) and can be directly coupled to an atmospheric model. The number of tiles (and patches for nature) is flexible. Currently, the number of patches for a nature tile can vary from 1 to 12 , and some tiles can be transformed (e.g. inland water to nature, or town to rocks) allowing a high degree of flexibility for specific applications. SURFEX includes some specific features for the coupling with atmospheric models: a parameterization of the subgrid-scale orographic friction, a simple onedimensional surface boundary layer model and the availability of implicit coupling with the atmosphere, which is necessary for long time steps (for numerical weather prediction or climate applications). SURFEX is able to adapt to a large range of grid sizes, from hundreds of kilometres, when coupled to a global climate model, to several metres in the case of large eddy simulations. SURFEX is also used for hydrological applications at scales from global to several tens of $\mathrm{km}$.
Another originality of the SURFEX individual models is probably the large number of options in ISBA that allow various degrees of sophistication in almost all compartments: soil, vegetation and carbon variables, hydrology and snow. ISBA is able to describe vertical heterogeneities in the soil and to account for different soil depths according to the vegetation type. The latter point is important for hydrological simulations and agricultural applications (e.g. Calvet et al., 2012). Since the recent introduction of Crocus (Vionnet et al., 2012), SURFEX covers the whole range of the snow model complexity, from the single layer bulk model to a multilayer model describing snow metamorphism. The TEB model was the first model to use the canyon approach to simulate fluxes with the atmosphere. It also simulates wet processes (surface water, snow cover, water exchanges in gardens). Besides classical applications in NWP, it can be used to estimate the energy consumption in relation with meteorological conditions. Its capacity to simulate the micro climate in the street, human comfort, hydrology, and vegetation processes in the street allows it to be used for urban planning. In addition, SURFEX coupling with ocean models, associated with an improvement of the air-sea surface flux representation (Lebeaupin Brossier et al., 2008, 2009), is also a significant benefit for medium- to long-term simulations.

Finally, SURFEX has an assimilation system fully compatible with the physics of the model. The assimilation system is presently used for operational numerical weather forecasting and for land-surface monitoring (Barbu et al., 2011).

\section{Perspectives}

The development and validation work will be actively pursued in the coming years in order to increase the domain of use for SURFEX and its realism. At present, there are some technical limitations for large grids (e.g. global grids for NWP) that must be solved. This implies an optimization and parallelization of the code, in particular the preparation of physiographic and initial fields. Other improvements are needed from a scientific point of view. For instance, the present version of ISBA, does not account for interactions between low vegetation or snowpack and the surrounding high vegetation, which impairs the quality of the model for the simulation of near-surface variables and the interpretation of satellite data. The lumped energy budget of ISBA lead to discrepancies in the SnowMIP2 runs in forest (Rutter et al., 2009). The surface energy budget will be improved to consider separate energy budgets for soil, snow and vegetation (above or partially covered by snow). The use of a separate budget for soil and vegetation will introduce a vegetation temperature that will allow a more accurate estimation of photosynthesis, vegetation growth and a better interpretation of satellite data in the infrared band. Through the interaction of the multiple energy budget with all the other parameterizations of ISBA, the strategy will be to build and validate 
a configuration that includes the most advanced parameterizations (multiple energy budget, explicit simulation of photosynthesis, multilayer soil and multilayer snow model, permafrost) that will be used as a reference to design simplified configurations for the various uses of SURFEX. In the future, ISBA will be completed by coupling with a Dynamic Global Vegetation Model. The dynamic vegetation applications will focus on simulating shifts in potential vegetation and its associated biogeochemical and hydrological cycles in response to shifts in climate while the hydrological applications will focus on the interaction between the surface and the groundwater. An interactive coupling between SURFEX and a regional (Habets et al., 2008) or global (Vergnes and Decharme, 2012; Vergnes et al., 2012) aquifer model will be developed.

TEB will be completed for energy consumption (Bueno et al., 2012), renewable energy production and vegetation (vegetated roofs) processes, allowing more detailed studies of the urban environment, including adaptation studies (Masson et al., 2013). The reference configuration of SURFEX for oceans will consist of parameterizations that account for the ocean surface state (waves and sprays) in the calculation of surface turbulent fluxes. This configuration will be extensively tested so as to define simplified versions suited to the various domains of application.

The development of the assimilation will focus on albedo, FaPAR (Fraction of Absorbed Photosynthetically Active Radiation) and land surface temperature, in order to progressively build a land data assimilation system.

SURFEX has been designed with a modular structure, which means that new elements of the sciences concerned can be easily introduced as new models or options. A steering committee has recently been set up to coordinate the scientific and technical evolution of the code to ensure that SURFEX will remain a state-of-the-art model in both aspects. For further details, including how to obtain a copy of the code, see http://www.cnrm.meteo.fr/surfex/.

\section{Supplementary material related to this article is available online at: http://www.geosci-model-dev.net/6/ 929/2013/gmd-6-929-2013-supplement.pdf.}

Acknowledgements. This paper is dedicated to the memory of Joël Noilhan who left us too early. Joël was at the origin of the first version of ISBA in the 80s. From then on, he was continuously involved in land surface model development and validation, he oversaw or assisted all the developments described in this paper and he initiated SURFEX. His enthusiasm, his seemingly boundless energy and his scientific leadership were sources of motivation for all of us and we sincerely hope that we can continue to successfully build upon the research he initiated over 20 years ago. The authors thank the numerous students and colleagues who were involved in the scientific and technical development of SURFEX and its scientific submodels. S. Lafont and A. Barbu were supported by the GEOLAND2 project, co-funded by the European Commission within the GMES initiative in FP7, and by the FP7 GHG-Europe project. The work on the introduction of Crocus in SURFEX for snow research was partially supported by the French LEFE/IDAO programme under the INEV project. Recent advances in TEB were developed in the framework of the VURCA (ANR-08-VULN-013), MUSCADE (ANR-09-VILL-0003) and VEGDUD (ANR-09-VILL-0007) projects of the French Agence Nationale de la Recherche.

Edited by: P. Jöckel

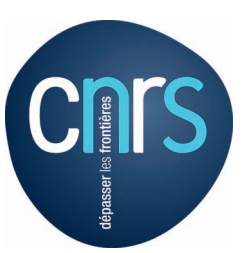

The publication of this article is financed by CNRS-INSU.

\section{References}

Albergel, C., Calvet, J.-C., Gibelin, A.-L., Lafont, S., Roujean, J.L., Berne, C., Traullé, O., and Fritz, N.: Observed and modelled ecosystem respiration and gross primary production of a grassland in southwestern France, Biogeosciences, 7, 1657-1668, doi:10.5194/bg-7-1657-2010, 2010a.

Albergel, C., Calvet, J.-C., Mahfouf, J.-F., Rüdiger, C., Barbu, A. L., Lafont, S., Roujean, J.-L., Walker, J. P., Crapeau, M., and Wigneron, J.-P.: Monitoring of water and carbon fluxes using a land data assimilation system: a case study for southwestern France, Hydrol. Earth Syst. Sci., 14, 1109-1124, doi:10.5194/hess-14-1109-2010, 2010b.

Alkama, R., Decharme, B., Douville, H., Becker, M., Cazenave, A., Sheffield, J., Voldoire, A., Tyteca, S., and Le Moigne, P.: Global Evaluation of the ISBA-TRIP Continental Hydrological System, Part I: Comparison to GRACE Terrestrial Water Storage Estimates and In Situ River Discharges, J. Hydrometeorol., 11, 583600, 2010.

Anderson, E. A.: A point energy and mass balance model of a snow cover, NOAA Tech. Rep. NWS 19, 150 pp., 1976.

Armstrong, A. and Brun, E.: Snow and Climate, Physical Processes, Surface Energy Exchange and Modeling, Cambridge University press, 222 pp., 1998.

Baldocchi, D. D., Hicks, B. B., and Camara, P.: A canopy stomatal resistance model for gaseous deposition to vegetated surfaces, Atmos. Environ., 21, 91-101, 1987.

Balsamo, G., Viterbo, P., Beljaars, A., van den Hurk, B., Hirschi, M., Betts, A. K., and Scipal, K.: A Revised Hydrology for the ECMWF Model: Verification from Field Site to Terrestrial Water Storage and Impact in the Integrated Forecast System, J. Hydrometeor., 10, 623-643, 2009.

Barbu, A. L., Calvet, J.-C., Mahfouf, J.-F., Albergel, C., and Lafont, S.: Assimilation of Soil Wetness Index and Leaf Area Index into the ISBA-A-gs land surface model: grassland case study, Biogeosciences, 8, 1971-1986, doi:10.5194/bg-8-1971-2011, 2011.

Bartelt, P. and Lehning, M.: A physical SNOWPACK model for the Swiss avalanche warning: Part I: numerical model, Cold Reg. 
Sci. Technol., 35, 123-145, 2002.

Bazile, E.: The soil water freezing in ISBA, HIRLAM Newsletter, 33, Proceedings of the ASM HIRLAM, 15-17 March, 92-95, 1999.

Bazile, E., El Haiti, M., Bogatchev, A., and Spiridonov, V.: Improvement of the snow parameterisation in ARPEGE/ALADIN, SRNWP/HIRLAM Workshop on surface processes, turbulence and mountain effects, Madrid, 22-24 October, 14-19, 2001.

Bélair, S., Crevier, L.-P., Mailhot, J., Bilodeau, B., and Delage, Y.: Operational Implementation of the ISBA Land Surface Scheme in the Canadian Regional Weather Forecast Model, Part I: Warm Season Results, J. Hydrometeorol., 4, 352-370, 2003.

Belamari, S.: Report on uncertainty estimates of an optimal bulk formulation for surface turbulent fluxes, Marine EnviRonment and Security for the European Area - Integrated Project (MERSEA IP), Deliverable D4.1.2, 29 pp., 2005.

Belamari, S. and Pirani, A.: Validation of the optimal heat and momentum fluxes using the ORCA2-LIM global ocean-ice model, Marine EnviRonment and Security for the European Area - Integrated Project (MERSEA IP), Deliverable D4.1.3, 88 pp., 2007.

Beljaars, A. C. M., Brown, A. R., and Wood, N.: A new parametrization of turbulent orographic form drag, Q. J. R. Meteorol. Soc., 130, 1327-1347, 2004.

Bellassen, V., Maire, G. L., Dhôte, J., Ciais, P., and Viovy, N.: Modelling forest management within a global vegetation model - Part 1: Model structure and general behaviour, Ecol. Model., 221, 2458-2474, 2010.

Best, M. J., Beljaars, A., Polcher, J., and Viterbo, P.: A Proposed Structure for Coupling Tiled Surfaces with the Planetary Boundary Layer, J. Hydrometeorol., 5, 1271-1278, 2004.

Best, M. J., Grimmond, C., and Villani, M.: Evaluation of the Urban Tile in MOSES using Surface Energy Balance Observations, Bound.-Lay. Meteorol., 118, 503-525, 2006.

Best, M. J., Pryor, M., Clark, D. B., Rooney, G. G., Essery, R. L. H., Ménard, C. B., Edwards, J. M., Hendry, M. A., Porson, A., Gedney, N., Mercado, L. M., Sitch, S., Blyth, E., Boucher, O., Cox, P. M., Grimmond, C. S. B., and Harding, R. J.: The Joint UK Land Environment Simulator (JULES), model description Part 1: Energy and water fluxes, Geosci. Model Dev., 4, 677-699, doi:10.5194/gmd-4-677-2011, 2011.

Beven, K. J. and Kirkby, M. J.: A physically based, variable contributing area model of basin hydrology / Un modèle à base physique de zone d'appel variable de l'hydrologie du bassin versant, Hydrol. Sci. Bull., 24, 43-69, 1979.

Bhumralkar, C. M.: Numerical Experiments on the Computation of Ground Surface Temperature in an Atmospheric General Circulation Model, J. Appl. Meteor., 14, 1246-1258, 1975.

Blackadar, A.-K.: Modeling the nocturnal boundary layer, Third Symp. on Atmospheric Turbulence, Diffusion and Air Quality, Boston, Am. Meteorol. Soc., 46-49, 1976.

Blanchard, D. C.: The production, distribution and bacterial enrichment of the sea-salt aerosol, in: Air-sea exchanges of Gas and Particles, edited by: Liss, P. S. and Slinn, W. G. N., D. Reidel Publishing Company, Dordrecht, 407-454, 1983.

Blanke, B. and Delecluse, P.: Variability of the Tropical Atlantic Ocean Simulated by a General Circulation Model with Two Different Mixed-Layer Physics, J. Phys. Oceanogr., 23, 1363-1388, 1993.
Boone, A.: Modelisation des processus hydrologiques dans le schema de surface ISBA: Inclusion d'un reservoir hydrologique, du gel et modelisation de la neige, Ph.D. dissertation, University Paul Sabatier, Toulouse, France, 2000 (in French).

Boone, A. and Etchevers, P.: An intercomparison of three snow schemes of varying complexity coupled to the same land surface model: Local-scale evaluation at an Alpine site, J. Hydrometeorol., 2, 374-394, 2001.

Boone, A., Calvet, J. C., and Noilhan, J.: Inclusion of a third soil layer in a land surface scheme using the force-restore method, J. Appl. Meteorol., 38, 1611-1630, 1999.

Boone, A., Masson, V., Meyers, T., and Noilhan, J.: The influence of the inclusion of soil freezing on simulations by a soil-vegetationatmosphere transfer scheme, J. Appl. Meteorol., 39, 1544-1569, 2000.

Boone, A., Habets, F., Noilhan, J., Clark, D., Dirmeyer, P., Fox, S., Gusev, Y., Haddeland, I., Koster, R., Lohmann, D., Mahanama, S., Mitchell, K., Nasonova, O., Niu, G. Y., Pitman, A., Polcher, J., Shmakin, A. B., Tanaka, K., van den Hurk, B., Verant, S., Verseghy, D., Viterbo, P., and Yang, Z. L.: The Rhoneaggregation land surface scheme intercomparison project: An overview, J. Climate, 17, 187-208, 2004.

Boone, A., de Rosnay, P., Balsamo, G., Beljaars, A., Chopin, F., Decharme, B., Delire, C., Ducharne, A., Gascoin, S., Grippa, M., Guichard, F., Gusev, Y., Harris, P., Jarlan, L., Kergoat, L., Mougin, E., Nasonova, O., Norgaard, A., Orgeval, T., Ottle, C., Poccard-Leclercq, I., Polcher, J., Sandholt, I., Saux-Picart, S., Taylor, C., and Xue, Y. K.: The Amma Land Surface Model Intercomparison Project (ALMIP), Bull. Am. Meteorol. Soc., 90, 1865-1880, 2009.

Bouilloud, L., Chancibault, K., Vincendon, B., Ducrocq, V., Habets, F., Saulnier, G. M., Anquetin, S., Martin, E., and Noilhan, J.: Coupling the ISBA Land Surface Model and the TOPMODEL Hydrological Model for Mediterranean Flash-Flood Forecasting: Description, Calibration, and Validation, J. Hydrometeorol., 11, 315-333, 2010.

Braud, I., Noilhan, J., Bessemoulin, P., Mascart, P., Haverkamp, R., and Vauclin, M.: Bare-ground surface heat and water exchanges under dry conditions: Observations and parameterization, Bound.-Lay. Meteorol., 66, 173-200, 1993.

Brooks, R. H. and Corey, A. T.: Properties of porous media affecting fluid flow, J. Irrig. Drain. Am. Soc. Civil Eng., 17, 187-208, 1966.

Brousseau, P., Berre, L., Bouttier, F., and Desroziers, G.: Background-error covariances for a convective-scale dataassimilation system: AROME-France 3D-Var, Q. J. R. Meteorol. Soc., 137, 409-422, 2011.

Brun, E., Martin, E., Simon, V., Gendre, C., and Coléou, C.: An energy and mass model of snow cover suitable for operational avalanche forecasting, J. Glaciol., 35, 333-342, 1989.

Brun, E., David, P., Sudul, M., and Brunot, G.: A numerical model to simulate snow-cover stratigraphy for operational avalanche forecasting, J. Glaciol., 38, 13-22, 1992.

Brun, E., Six, D., Picard, G., Vionnet, V., Arnaud, L., Bazile, E., Boone, A., Bouchard, A., Genthon, C., Guidard, V., Le Moigne, P., Rabier, F., and Seity, Y.: Snow/atmosphere coupled simulation at Dome C, Antarctica, J. Glaciol., 52, 721-736, 2011.

Brun, E., Vionnet, V., Decharme, B., Peings, Y., and Valette, R.: Simulation of Northern Eurasian Local Snow Depth, Mass, and 
Density Using a Detailed Snowpack Model and Meteorological Reanalyses, J. Hydrometeor., 14, 203-219, doi:10.1175/JHM-D12-012.1, 2013.

Brut, A., Rüdiger, C., Lafont, S., Roujean, J.-L., Calvet, J.-C., Jarlan, L., Gibelin, A.-L., Albergel, C., Le Moigne, P., Soussana, J.-F., Klumpp, K., Guyon, D., Wigneron, J.-P., and Ceschia, E.: Modelling LAI at a regional scale with ISBA-A-gs: comparison with satellite-derived LAI over southwestern France, Biogeosciences, 6, 1389-1404, doi:10.5194/bg-6-1389-2009, 2009.

Bueno, B., Pigeon, G., Norford, L. K., Zibouche, K., and Marchadier, C.: Development and evaluation of a building energy model integrated in the TEB scheme, Geosci. Model Dev., 5, 433-448, doi:10.5194/gmd-5-433-2012, 2012.

Calvet, J. C.: Investigating soil and atmospheric plant water stress using physiological and micrometeorological data, Agr. Forest Meteorol., 103, 229-247, 2000.

Calvet, J. C. and Soussana, J. F.: Modelling $\mathrm{CO}_{2}$-enrichment effects using an interactive vegetation SVAT scheme, Agr. Forest Meteorol., 108, 129-152, 2001.

Calvet, J. C., Noilhan, J., Roujean, J. L., Bessemoulin, P., Cabelguenne, M., Olioso, A., and Wigneron, J. P.: An interactive vegetation SVAT model tested against data from six contrasting sites, Agr. Forest Meteorol., 92, 73-95, 1998.

Calvet, J. C., Rivalland, V., Picon-Cochard, C., and Guehl, J. M.: Modelling forest transpiration and $\mathrm{CO}_{2}$ fluxes - response to soil moisture stress, Agr. Forest Meteorol., 124, 143-156, 2004.

Calvet, J.-C., Gibelin, A.-L., Roujean, J.-L., Martin, E., Le Moigne, P., Douville, H., and Noilhan, J.: Past and future scenarios of the effect of carbon dioxide on plant growth and transpiration for three vegetation types of southwestern France, Atmos. Chem. Phys., 8, 397-406, doi:10.5194/acp-8-397-2008, 2008.

Calvet, J.-C., Lafont, S., Cloppet, E., Souverain, F., Badeau, V., and Le Bas, C.: Use of agricultural statistics to verify the interannual variability in land surface models: a case study over France with ISBA-A-gs, Geosci. Model Dev., 5, 37-54, doi:10.5194/gmd-537-2012, 2012.

Caniaux, G., Belamari, S., Giordani, H., and Paci, A.: A 1 Year Sea Surface Heat Budget in the North Eastern Atlantic Basin during the POMME Experiment: Part II : Flux Correction, J. Geophys. Res., 110, C07S03, doi:10.1029/2004JC002695, 2005.

Carrer, D., Lafont, S., Roujean, J.-L., Calvet, J.-C., Meurey, C., Le Moigne, P., and Trigo, I. : Incoming solar and infrared radiation derived from METEOSAT: impact on the modelled land water and energy budget over France, J. Hydrometeor., 13, 504-520, 2012.

Charnock, H.: Wind stress on a water surface, Q. J. R. Meteorol. Soc., 81, 639-640, 1955.

Chen, T. H., Henderson-Sellers, A., Milly, P. C. D., Pitman, A. J., Beljaars, A. C. M., Polcher, J., Abramopoulos, F., Boone, A., Chang, S., Chen, F., Dai, Y., Desborough, C. E., Dickinson, R. E., Dümenil, L., Ek, M., Garratt, J. R., Gedney, N., Gusev, Y. M., Kim, J., Koster, R., Kowalczyk, E. A., Laval, K., Lean, J., Lettenmaier, D., Liang, X., Mahfouf, J.-F., Mengelkamp, H.-T., Mitchell, K., Nasonova, O. N., Noilhan, J., Robock, A., Rosenzweig, C., Schaake, J., Schlosser, C. A., Schulz, J.-P., Shao, Y., Shmakin, A. B., Verseghy, D. L., Wetzel, P., Wood, E. F., Xue, Y., Yang, Z.-L., and Zeng, Q.: Cabauw Experimental Results from the Project for Intercomparison of Land-Surface Parameterization Schemes, J. Climate, 10, 1194-1215, 1997.
Cherkauer, K. A. and Lettenmaier, D. P.: Hydrologic effects of frozen soils in the upper Mississippi River basin, J. Geophys. Res., 104, 19599-19610, 1999.

Clapp, R. B. and Hornberger, G. M.: Empirical equations for some soil hydraulic properties, Water Resour. Res., 14, 601-604, 1978.

Clark, D. B., Mercado, L. M., Sitch, S., Jones, C. D., Gedney, N., Best, M. J., Pryor, M., Rooney, G. G., Essery, R. L. H., Blyth, E., Boucher, O., Harding, R. J., Huntingford, C., and Cox, P. M.: The Joint UK Land Environment Simulator (JULES), model description - Part 2: Carbon fluxes and vegetation dynamics, Geosci. Model Dev., 4, 701-722, doi:10.5194/gmd-4-701-2011, 2011.

Collatz, G., Ribas-Carbo, M., and Berry, J.: Coupled Photosynthesis-Stomatal Conductance Model for Leaves of C4 Plants, Funct. Plant Biol., 19, 519-538, 1992.

Courtier, P., Freydier, C., Geleyn, J.-F., Rabier, F., and Rochas, M.: The ARPEGE project at Météo-France, ECMWF workshop on numerical methods in atmospheric modeling, 2, 193-231, 1991.

Crumeyrolle, S., Tulet, P., Gomes, L., Garcia-Carreras, L., Flamant, C., Parker, D. J., Matsuki, A., Formenti, P., and Schwarzenboeck, A.: Transport of dust particles from the Bodélé region to the monsoon layer - AMMA case study of the 9-14 June 2006 period, Atmos. Chem. Phys., 11, 479-494, doi:10.5194/acp-11479-2011, 2011.

Deardorff, J. W.: A Parameterization of Ground-Surface Moisture Content for Use in Atmospheric Prediction Models, J. Appl. Meteor., 16, 1182-1185, 1977.

Decharme, B. and Douville, H.: Introduction of a sub-grid hydrology in the ISBA land surface model, Clim. Dynam., 26, 65-78, 2006 a.

Decharme, B. and Douville, H.: Uncertainties in the GSWP-2 precipitation forcing and their impacts on regional and global hydrological simulations, Clim. Dynam., 27, 695-713, $2006 \mathrm{~b}$.

Decharme, B. and Douville, H.: Global validation of the ISBA subgrid hydrology, Clim. Dynam., 29, 21-37, 2007.

Decharme, B., Douville, H., Boone, A., Habets, F., and Noilhan, J.: Impact of an exponential profile of saturated hydraulic conductivity within the ISBA LSM: Simulations over the Rhone Basin, J. Hydrometeorol., 7, 61-80, 2006.

Decharme, B., Douville, H., Prigent, C., Papa, F., and Aires, F.: A new river flooding scheme for global climate applications: Off-line evaluation over South America, J. Geophys. Res., 113, D11110, doi:10.1029/2007JD009376, 2008.

Decharme, B., Alkama, R., Douville, H., Becker, M., and Cazenave, A.: Global Evaluation of the ISBA-TRIP Continental Hydrological System. Part II: Uncertainties in River Routing Simulation Related to Flow Velocity and Groundwater Storage, J. Hydrometeorol., 11, 601-617, 2010.

Decharme, B., Boone, A., Delire, C., and Noilhan, J.: Local evaluation of the Interaction between Soil Biosphere Atmosphere soil multilayer diffusion scheme using four pedotransfer functions, J. Geophys. Res., 116, D20126, doi:10.1029/2011JD016002, 2011.

Decharme, B., Alkama, R., Papa, F., Faroux, S., Douville, H., and Prigent, C.: Global off-line evaluation of the ISBA-TRIP flood model, Clim. Dynam., 38, 1389-1412, doi:10.1007/s00382-0111054-9, 2012.

Dee, D. P., Uppala, S. M., Simmons, A. J., Berrisford, P., Poli, P., Kobayashi, S., Andrae, U., Balmaseda, M. A., Balsamo, G., Bauer, P., Bechtold, P., Beljaars, A. C. M., van de Berg, L., Bidlot, J., Bormann, N., Delsol, C., Dragani, R., Fuentes, M., Geer, 
A. J., Haimberger, L., Healy, S. B., Hersbach, H., Holm, E. V., Isaksen, L., Kallberg, P., Köhler, M., Matricardi, M., McNally, A. P., Monge-Sanz, B. M., Morcrette, J.-J., Park, B.-K., Peubey, C., de Rosnay, P., Tavolato, C., Thépaut, J.-N., and Vitart, F.: The ERA-Interim reanalysis: configuration and performance of the data assimilation system, Q. J. R. Meteorol. Soc., 137, 553-597, 2011.

Dirmeyer, P. A., Dolman, A. J., and Sato, N.: The Pilot Phase of the Global Soil Wetness Project, Bull. Amer. Meteor. Soc., 80, 851-878, 1999.

Dirmeyer, P. A., Gao, X., Zhao, M., Guo, Z., Oki, T., and Hanasaki, N.: GSWP-2: Multimodel Analysis and Implications for Our Perception of the Land Surface, Bull. Amer. Meteor. Soc., 87, 13811397, 2006.

Douville, H., Royer, J.-F., and Mahfouf, J.-F.: A new snow parameterization for the French community climate model. Part I: Validation in stand-alone experiments, Clim. Dynam., 12, 21-35, 1995.

Douville, H., Viterbo, P., Mahfouf, J.-F., and Beljaars, A. C. M.: Evaluation of the Optimum Interpolation and Nudging Techniques for Soil Moisture Analysis Using FIFE Data, Mon. Weather Rev., 128, 1733-1756, 2000.

Draper, C. S., Mahfouf, J. F., and Walker, J. P.: An EKF assimilation of AMSR-E soil moisture into the ISBA land surface scheme, J. Geophys. Res.-Atmos., 114, D20104, doi:10.1029/2008JD011650, 2009.

Draper, C. S., Mahfouf, J.-F., Calvet, J.-C., Martin, E., and Wagner, W.: Assimilation of ASCAT near-surface soil moisture into the SIM hydrological model over France, Hydrol. Earth Syst. Sci., 15, 3829-3841, doi:10.5194/hess-15-3829-2011, 2011 a.

Draper, C. S., Mahfouf, J.-F., and Walker, J. P.: Root zone soil moisture from the assimilation of screen-level variables and remotely sensed soil moisture, J. Geophys. Res., 116, D02127, doi:10.1029/2010JD013829, 2011b.

Dümenil, H. and Todoni, E.: A rainfall-runoff scheme for use in the Hamburg climate model, Adv. Theor. Hydrol., 9, 129-157, 1992.

Dupont, S. and Mestayer, P. G.: Parameterization of the Urban Energy Budget with the Submesoscale Soil Model, J. Appl. Meteor. Climatol., 45, 1744-1765, 2006.

Ek, M. B., Mitchell, K. E., Lin, Y., Rogers, E., Grunmann, P., Koren, V., Gayno, G. and Tarpley, J. D.: Implementation of Noah land surface model advances in the National Centers for Environmental Prediction operational mesoscale Eta model, J. Geophys. Res., 108, 8851, doi:10.1029/2002JD003296, 2003.

Essery, R., Best, M. J., Betts, R. A., Cox, P. M., and Taylor, C. M.: Explicit Representation of Subgrid Heterogeneity in a GCM Land Surface Scheme J. Hydrometeorol., 4, 530-543, 2003.

Essery, R., Morin, S., Lejeune, Y., and Bauduin-Ménard, C.: A comparison of 1701 snow models using observations from an alpine site, Advances in Water Resources, 55, 131-148, doi:10.1016/j.advwatres.2012.07.013, 2013.

Etchevers, P., Golaz, C., and Habets, F.: Simulation of the water budget and the river flows of the Rhone basin from 1981 to 1994 , J. Hydrol., 244, 60-85, 2001.

Etchevers, P., Martin, E., Brown, R., Fierz, C., Lejeune, Y., Bazile, E., Boone, A., Dai, Y.-J., Essery, R., Fernandez, A., Gusev, Y., Jordan, R., Koren, V., Kowalczyk, E., Nasonova, N. O., Pyles, R. D., Schlosser, A., Shmakin, A. B., Smirnova, T. G., Strasser, U., Verseghy, D., Yamazaki, T., and Yang, Z.-L.: Intercomparison of the surface energy budget simulated by several snow models (SNOWMIP project), Ann. Glaciol., 38, 150-158, 2003.

Fairall, C. W., Bradley, E. F., Hare, J. E., Grachev, A. A., and Edson, J. B.: Bulk parameterization of air-sea fluxes : Updates and verification for the COARE algorithm, J. Climate, 16, 571-591, 2003.

Fan, Y., Wood, E., Baeck, M., and Smith, J.: The fractional coverage of rainfall over a grid: Analyses of NEXRAD data over the southern plains, Water Resour. Res., 32, 2787-2802, 1996.

FAO: World reference base for soil resources 2006, A framework for international classification, correlation and communication, World soil resources report No. 103, Food and Agriculture Organization of the United Nations, 2006.

Farouki, O.: Thermal Properties of Soils, Series on Rock and Soil Mechanics, 11, Trans. Tech., 1986.

Faroux, S., Kaptué Tchuenté, A. T., Roujean, J.-L., Masson, V., Martin, E., and Le Moigne, P.: ECOCLIMAP-II/Europe: a twofold database of ecosystems and surface parameters at $1 \mathrm{~km}$ resolution based on satellite information for use in land surface, meteorological and climate models, Geosci. Model Dev., 6, 563582, doi:10.5194/gmd-6-563-2013, 2013.

Farquhar, G. D., von Caemmerer, S., and Berry, J. A.: A biochemical model of photosynthetic $\mathrm{CO} 2$ assimilation in leaves of $\mathrm{C} 3$ species, Planta, 149, 78-90, 1980.

Farr, T. G., Rosen, P. A., Caro, E., Crippen, R., Duren, R., Hensley, S., Kobrick, M., Paller, M., Rodriguez, E., Roth, L., Seal, D., Shaffer, S., Shimada, J., Umland, J., Werner, M., Oskin, M., Burbank, D., and Alsdorf, D.: The Shuttle Radar Topography Mission, Rev. Geophys., 45, RG2004, doi:10.1029/2005RG000183, 2007.

Fischer, C., Montmerle, T., Berre, L., Auger, L., and Ştefanescu, S. E.: An overview of the variational assimilation in the ALADIN/France numerical weather-prediction system, Q. J. R. Meteorol. Soc., 131, 3477-3492, 2005.

Fuchs, M., Campbell, G. S., and Papendick, R. I.: An analysis of sensible and latent heat flow in a partially frozen unsaturated soil., Soil Sci. Soc. Am. J., 42, 379-385, 1978.

Galle, A., Florez-Sarasa, I., Tomas, M., Pou, A., Medrano, H., Ribas-Carbo, M., and Flexas, J.: The role of mesophyll conductance during water stress and recovery in tobacco (Nicotiana sylvestris): acclimation or limitation?, J. Exp. Bot., 60, 23792390, 2009.

Gaspar, P., Grégoris, Y., and Lefevre, J.-M.: A Simple Eddy Kinetic Energy Model for Simulations of the Oceanic Vertical Mixing: Tests at Station Papa and Long-Term Upper Ocean Study Site, J. Geophys. Res., 95, 16179-16193, 1990.

Georgelin, M., Richard, E., Petitdidier, M., and Druilhet, A.: Impact of Subgrid-Scale Orography Parameterization on the Simulation of Orographic Flows, Mon. Weather Rev., 122, 15091522, 1994.

Gerard, L., Piriou, J.-M., Brožková, R., Geleyn, J.-F., and Banciu, D.: Cloud and Precipitation Parameterization in a Meso-GammaScale Operational Weather Prediction Model, Mon. Weather Rev., 137, 3960-3977, 2009.

Gesch, D., Verdin, K., and Greenlee, S.: New Land Surface Digital Elevation Model Covers the Earth, EOS T. Am. Geophys. Un., 80, 69-70, 1999.

Giard, D. and Bazile, E.: Assimilation of soil temperature and water content with ISBA in ARPEGE: some new developments and 
tests, HIRLAM Newsletter, 24, 34-42, 1996.

Giard, D. and Bazile, E.: Implementation of a New Assimilation Scheme for Soil and Surface Variables in a Global NWP Model, Mon. Weather Rev., 128, 997-1015, 2000.

Gibelin, A. L., Calvet, J. C., Roujean, J. L., Jarlan, L.- and Los, S. O.: Ability of the land surface model ISBA-A-gs to simulate leaf area index at the global scale: Comparison with satellites products, J. Geophys. Res., 111, D18102, doi:10.1029/2005JD006691, 2006.

Gibelin, A.-L., Calvet, J.-C., and Viovy, N.: Modelling energy and $\mathrm{CO}_{2}$ fluxes with an interactive vegetation land surface modelEvaluation at high and middle latitudes, Agr. Forest Meteorol., 148, 1611-1628, 2008.

Giordani, H., Caniaux, G., Prieur, L., Paci, A., and Giraud, S.: A One Year Mesoscale Simulation of the Northeast Atlantic : Mixed Layer Heat and Mass Budgets during the POMME Experiment, J. Geophys. Res., 110, C07S08, doi:10.1029/2004JC002765, 2005.

Giordani, H. and Caniaux, G.: Diagnosing Vertical Motion in the Equatorial Atlantic, Ocean Dynam., 61, 1995-2018, 2011.

Goudriaan, J., van Laar, H. H., van Keulen, H., and Louwerse, W. Photosynthesis, $\mathrm{CO} 2$ and plant production, in: Wheat growth and modelling, edited by: Day, W. and Atkin, R. K., Plenum Press, New York, Series A, 86, 107-122, 1985.

Grant, A. L. M. and Mason, P. J.: Observations of boundary-layer structure over complex terrain, Q. J. R. Meteorol. Soc., 116, 159186, 1990.

Green, W. H. and Ampt, G. A.: Studies on soil physics, 1: The flow of air and water through soils, J. Agric. Sci., 4, 1-24, 1911.

Grimmond, C. S. B., Blackett, M., Best, M. J., Barlow, J., Baik, J.-J., Belcher, S. E., Bohnenstengel, S. I., Calmet, I., Chen, F., Dandou, A., Fortuniak, K., Gouvea, M. L., Hamdi, R., Hendry, M., Kawai, T., Kawamoto, Y., Kondo, H., Krayenhoff, E. S., Lee, S.-H., Loridan, T., Martilli, A., Masson, V., Miao, S., Oleson, K., Pigeon, G., Porson, A., Ryu, Y.-H., Salamanca, F., ShashuaBar, L., Steeneveld, G.-J., Tombrou, M., Voogt, J., Young, D., and Zhang, N.: The International Urban Energy Balance Models Comparison Project: First Results from Phase 1, J. Appl. Meteorol. Climatol., 49, 1268-1292, 2010.

Grimmond, C. S. B., Blackett, M., Best, M. J., Baik, J.-J., Belcher, S. E., Beringer, J., Bohnenstengel, S. I., Calmet, I., Chen, F., Coutts, A., Dandou, A., Fortuniak, K., Gouvea, M. L., Hamdi, R., Hendry, M., Kanda, M., Kawai, T., Kawamoto, Y., Kondo, H., Krayenhoff, E. S., Lee, S.-H., Loridan, T., Martilli, A., Masson, V., Miao, S., Oleson, K., Ooka, R., Pigeon, G., Porson, A., Ryu, Y.-H., Salamanca, F., Steeneveld, G., Tombrou, M., Voogt, J. A., Young, D. T., and Zhang, N.: Initial results from Phase 2 of the international urban energy balance model comparison, Int. J. Climatol., 31, 244-272, 2011.

Grini, A., Tulet, P., and Gomes, L.: Dusty weather forecasts using the MesoNH mesoscale atmospheric model, J. Geophys. Res., 111, D19205, doi:10.1029/2005JD007007, 2006.

Guenther, A., Hewitt, C. N., Erickson, D., Fall, R., Geron, C., Graedel, T., Harley, P., Klinger, L., Lerdau, M., Mckay, W. A., Pierce, T., Scholes, B., Steinbrecher, R., Tallamraju, R., Taylor, J., and Zimmerman, P.: A global model of natural volatile organic compound emissions, J. Geophys. Res., 100, 8873-8892, 1995.

Habets, F. and Saulnier, G.-M.: Subgrid runoff parameterization, Phys. Chem. Earth, Pt. B, 26, 455-459, 2001.
Habets, F., Noilhan, J., Golaz, C., Goutorbe, J. P., Lacarrère, P., Leblois, E., Ledoux, E., Martin, E., Ottlé, C., and Vidal-Madjar, D.: The ISBA surface scheme in a macroscale hydrological model applied to the Hapex-Mobilhy area Part I: model and database, J. Hydrol., 217, 75-96, 1999a.

Habets, F., Noilhan, J., Golaz, C., Goutorbe, J. P., Lacarrère, P., Leblois, E., Ledoux, E., Martin, E., Ottlé, C., and Vidal-Madjar, D.: The ISBA surface scheme in a macroscale hydrological model applied to the Hapex-Mobilhy area Part II: simulation of streamflow and annual water budget, J. Hydrol., 217, 97-118, $1999 b$.

Habets, F., Boone, A., and Noilhan, J.: Simulation of a Scandinavian basin using the diffusion transfer version of ISBA, Global Planet. Change, 38, 137-149, 2003.

Habets, F., Le Moigne, P., and Noilhan, J.: On the utility of operational precipitation forecasts to serve as input for streamflow forecasting, J. Hydrol., 293, 270-288, 2004.

Habets, F., Boone, A., Champeaux, J. L., Etchevers, P., Franchisteguy, L., Leblois, E., Ledoux, E., Le Moigne, P., Martin, E., Morel, S., Noilhan, J., Segui, P. Q., Rousset-Regimbeau, F., and Viennot, P.: The SAFRAN-ISBA-MODCOU hydrometeorological model applied over France, J. Geophys. Res.-Atmos., 113, D06113, doi:10.1029/2007JD008548, 2008.

Hamdi, R. and Masson, V.: Inclusion of a Drag Approach in the Town Energy Balance (TEB) Scheme: Offline 1D Evaluation in a Street Canyon, J. Appl. Meteorol. Clim., 47, 2627-2644, 2008.

Hamdi, R., Degrauwe, D., and Termonia, P.: Coupling the Town Energy Balance (TEB) Scheme to an Operational Limited-Area NWP Model: Evaluation for a Highly Urbanized Area in Belgium, Weather Forecast., 27, 323-344, 2012.

Henderson-Sellers, A., Yang, Z.-L., and Dickinson, R. E.: The Project for Intercomparison of Land-surface Parameterization Schemes, Bull. Amer. Meteor. Soc., 74, 1335-1349, 1993.

Hostetler, S. W. and Bartlein, P. J.: Simulation of lake evaporation with application to modeling lake level variations of HarneyMalheur Lake, Oregon, Water Resour. Res., 26, 2603-2612, 1990.

Jackson, R. B., Canadell, J., Ehleringer, J. R., Mooney, H. A., Sala, O. E., and Schulze, E. D.: A global analysis of root distributions for terrestrial biomes, Oecologia, 108, 389-411, 1996.

Jacobs, C.: Direct impact of $\mathrm{CO}_{2}$ enrichment on regional transpiration, Ph.D. thesis, Agricultural University, Wageningen, The Netherlands, 1994.

Jacobs, C., van den Hurk, B., and de Bruin, H.: Stomatal behaviour and photosynthetic rate of unstressed grapevines in semi-arid conditions, Agr. Forest Meteorol., 80, 111-134, 1996.

Jarvis, P. G.: The interpretation in the variations of leaf water potential and stomatal conductance found in canopies in the field, Philos. T. R. Soc. Lon. B., 273, 593-610, 1976.

Johansen, O.: Thermal conductivity of soils, Ph.D. dissertation, University of Trondheim, Norway, 1975.

Johnsson, H. and Lundin, L.-C.: Surface runoff and soil water percolation as affected by snow and soil frost, J. Hydrol., 122, 141159, 1991.

Jordan, R.: A one-dimensional temperature model for a snow cover, CRREL Special Rep. 91-1b, Cold Regions Research and Engineering Laboratory, Hanover, NH, 49 pp., 1991.

Josse, P., Caniaux, G., Giordani, H., and Planton, S.: Intercomparaison of oceanic and atmospheric forced and coupled mesoscale 
simulations. Part I: Surface fluxes, Ann. Geophys., 17, 566-576, doi:10.1007/s00585-999-0566-7, 1999.

Kane, D. L. and Stein, J.: Water movement into seasonally frozen soils, Water Resour. Res., 19, 1547-1557, 1983.

Kantha, L. and Clayson, C.: An improved mixed layer model for geosphysical applications, J. Geophys. Res., 99, 25235-25266, 1994.

Kaptué Tchuenté, A., Roujean, J.-L., and Faroux, S. : ECOCLIMAP-II : An ecosystem classification and land surface parameters database of Western Africa at $1 \mathrm{~km}$ resolution for the African Monsoon Multidisciplinary Analysis (AMMA) project, Remote Sens. Environ., 114, 961-976, 2010.

Kondo, H., Genchi, Y., Kikegawa, Y., Ohashi, Y., Yoshikado, H., and Komiyama, H.: Development of a Multi-Layer Urban Canopy Model for the Analysis of Energy Consumption in a Big City: Structure of the Urban Canopy Model and its Basic Performance, Bound.-Lay. Meteorol., 116, 395-421, 2005.

Kourzeneva, E.: External data for lake parameterization in Numerical Weather Prediction and climate modeling, Boreal Env. Res., 15, 165-177, 2010.

Kourzeneva, E., Asensio, H., Martin, E., and Faroux, S.: Global gridded dataset of lake coverage and lake depth for use in numerical weather prediction and climate modelling, Tellus A, 64, 14 pp., 2012.

Krinner, G., Viovy, N., de Noblet-Ducoudré, N., Ogée, J., Polcher, J., Friedlingstein, P., Ciais, P., Sitch, S., and Prentice, I. C.: A dynamic global vegetation model for studies of the coupled atmosphere-biosphere system, Glob. Biogeochem. Cycles, 19, GB1015, doi:10.1029/2003GB002199, 2005.

Kumar, S. V., Peters-Lidard, C. D., Tian, Y., Houser, P. R., Geiger, J., Olden, S., Lighty, L., Eastman, J. L., Doty, B., Dirmeyer, P., Adams, J., Mitchell, K., Wood, E. F., and Sheffield, J.: Land Information System - An interoperable framework for high resolution land surface modeling, Environ. Modell. Softw., 21, 14021415,2006

Kustas, W. P. and Brutsaert, W.: Wind profile constants in a neutral atmospheric boundary layer over complex terrain, Bound.-Lay. Meteorol., 34, 35-54, 1986.

Lafont, S., Zhao, Y., Calvet, J.-C., Peylin, P., Ciais, P., Maignan, F., and Weiss, M.: Modelling LAI, surface water and carbon fluxes at high-resolution over France: comparison of ISBA-A-gs and ORCHIDEE, Biogeosciences, 9, 439-456, doi:10.5194/bg9-439-2012, 2012.

Lafore, J. P., Stein, J., Asencio, N., Bougeault, P., Ducrocq, V., Duron, J., Fischer, C., Héreil, P., Mascart, P., Masson, V., Pinty, J. P., Redelsperger, J. L., Richard, E., and Vilà-Guerau de Arellano, J.: The Meso-NH Atmospheric Simulation System. Part I: adiabatic formulation and control simulations, Ann. Geophys., 16, 90-109, doi:10.1007/s00585-997-0090-6, 1998.

Large, W., McWilliams, J., and Doney, S.: Ocean vertical mixing : a review and a model with nonlocal boundary layer parameterization, Rev. Geophys., 32, 363-403, 1994.

Lawrence, D., Oleson, K. W., Flanner, M. G., Thorton, P. E., Swenson, S. C., Lawrence, P. J., Zeng, X., Yang, Z.-L., Levis, S., Skaguchi, K., Bonan, G. B., and Slater, A. G.: Parameterization Improvements and Functional and Structural Advances in Version 4 of the Community Land Model, J. Adv. Model. Earth Syst., 3, 27 pp., 2011.
Lebeaupin Brossier, C., Ducrocq, V., and Giordani, H.: Sensitivity of three Mediterranean heavy rain events to two different sea surface fluxes parameterizations in highresolution numerical modeling, J. Geophys. Res., 113, D21109, doi:10.1029/2007JD009613, 2008

Lebeaupin Brossier, C., Ducrocq, V., and Giordani, H.: Two-way one-dimensional high-resolution air-sea coupled modelling applied to Mediterranean heavy rain events, Q. J. R. Meteorol. Soc., 135, 187-204, 2009.

Lemonsu, A., Grimmond, C. S. B., and Masson, V.: Modeling the surface energy balance of the core of an old Mediterranean city: Marseille, J. Appl. Meteorol., 43, 312-327, 2004.

Lemonsu, A., Masson, V., and Berthier, E.: Improvement of the hydrological component of an urban soil-vegetation-atmospheretransfer model, Hydrol. Process., 21, 2100-2111, 2007.

Lemonsu, A., Belair, S., and Mailhot, J. : The New Canadian Urban Modelling System: Evaluation for Two Cases from the Joint Urban 2003 Oklahoma City Experiment, Bound.-Lay. Meteorol., 133, 47-70, 2009

Lemonsu, A., Bélair, S., Mailhot, J., and Leroyer, S.: Evaluation of the Town Energy Balance Model in Cold and Snowy Conditions during the Montreal Urban Snow Experiment 2005, J. Appl. Meteorol. Climatol., 49, 346-362, 2010

Lemonsu, A., Masson, V., Shashua-Bar, L., Erell, E., and Pearlmutter, D.: Inclusion of vegetation in the Town Energy Balance model for modelling urban green areas, Geosci. Model Dev., 5, 1377-1393, doi:10.5194/gmd-5-1377-2012, 2012.

Leroyer, S., Mailhot, J., Bélair, S., Lemonsu, A., and Strachan, I. B.: Modeling the Surface Energy Budget during the Thawing Period of the 2006 Montreal Urban Snow Experiment, J. Appl. Meteorol. Clim., 49, 68-84, 2010.

Liang, X., Wood, E. F., Lettenmaier, D. P., Lohmann, D., Boone, A., Chang, S., Chen, F., Dai, Y. J., Desborough, C., Dickinson, R. E., Duan, Q. Y., Ek, M., Gusev, Y. M., Habets, F., Irannejad, P., Koster, R., Mitchell, K. E., Nasonova, O. N., Noilhan, J., Schaake, J., Schlosser, A., Shao, Y. P., Shmakin, A. B., Verseghy, D., Warrach, K., Wetzel, P., Xue, Y. K., Yang, Z. L., and Zeng, Q. C.: The Project for Intercomparison of Land-surface Parameterization Schemes (PILPS) phase 2(c) Red-Arkansas River basin experiment: 2. Spatial and temporal analysis of energy fluxes, Global Planet. Change, 19, 137-159, 1998.

Lohmann, D., Lettenmaier, D. P., Liang, X., Wood, E. F., Boone, A., Chang, S., Chen, F., Dai, Y. J., Desborough, C., Dickinson, R. E., Duan, Q. Y., Ek, M., Gusev, Y. M., Habets, F., Irannejad, P., Koster, R., Mitchell, K. E., Nasonova, O. N., Noilhan, J., Schaake, J., Schlosser, A., Shao, Y. P., Shmakin, A. B., Verseghy, D., Warrach, K., Wetzel, P., Xue, Y. K., Yang, Z. L., and Zeng, Q. C.: The Project for Intercomparison of Land-surface Parameterization Schemes (PILPS) phase 2(c) Red-Arkansas River basin experiment: 3. Spatial and temporal analysis of water fluxes, Global Planet. Change, 19, 161-179, 1998.

Loth, B., Graf, H.-F., and Oberhuber, J. M.: Snow Cover Model for Global Climate Simulations, J. Geophys. Res., 98, 10451-10464, 1993.

Louis, J.-F.: A parametric model of vertical eddy fluxes in the atmosphere, Bound.-Lay. Meteorol., 17, 187-202, 1979.

Luo, L. F., Robock, A., Vinnikov, K. Y., Schlosser, C. A., Slater, A. G., Boone, A., Braden, H., Cox, P., de Rosnay, P., Dickinson, R. E., Dai, Y. J., Duan, Q. Y., Etchevers, P., Henderson-Sellers, 
A., Gedney, N., Gusev, Y. M., Habets, F., Kim, J. W., Kowalczyk, E., Mitchell, K., Nasonova, O. N., Noilhan, J., Pitman, A. J., Schaake, J., Shmakin, A. B., Smirnova, T. G., Wetzel, P., Xue, Y. K., Yang, Z. L., and Zeng, Q. C.: Effects of frozen soil on soil temperature, spring infiltration, and runoff: Results from the PILPS 2(d) experiment at Valdai, Russia, J. Hydrometeorol., 4, 334-351, 2003.

Lynch-Stieglitz, M.: The Development and Validation of a Simple Snow Model for the GISS GCM, J. Climate, 7, 1842-1855, 1994.

Mahfouf, J.-F.: Analysis of Soil Moisture from Near-Surface Parameters: A Feasibility Study, J. Appl. Meteorol., 30, 1534-1547, 1991.

Mahfouf, J.-F.: Assimilation of satellite-derived soil moisture from ASCAT in a limited-area NWP model, Q. J. R. Meteorol. Soc., 136, 784-798, 2010.

Mahfouf, J.-F. and Bliznak, V.: Combined assimilation of screenlevel observations and radar-derived precipitation for soil moisture analysis, Q. J. R. Meteorol. Soc., 137, 709-722, 2011.

Mahfouf, J. F. and Noilhan, J.: Inclusion of gravitational drainage in a land surface scheme based on the force-restore method, J. Appl. Meteorol., 35, 987-992, 1996.

Mahfouf, J. F., Manzi, A. O., Noilhan, J., Giordani, H., and Deque, M.: The Land-surface Scheme ISBA Within the Meteo-France Climate Model Arpege. 1. Implementation and Preliminaryresults, J. Climate, 8, 2039-2057, 1995.

Mahfouf, J. F., Bergaoui, K., Draper, C., Bouyssel, F., Taillefer, F., and Taseva, L.: A comparison of two off-line soil analysis schemes for assimilation of screen level observations, J. Geophys. Res., 114, D08105, doi:10.1029/2008JD011077, 2009.

Marticorena, B. and Bergametti, G.: Modeling the atmospheric dust cycle: 1. Design of a soil-derived dust emission scheme, J. Geophys. Res., 100, 16415-16430, 1995.

Martilli, A.: Numerical Study of Urban Impact on Boundary Layer Structure: Sensitivity to Wind Speed, Urban Morphology, and Rural Soil Moisture, J. Appl. Meteorol., 41, 1247-1266, 2002.

Mascart, P., Noilhan, J., and Giordani, H. : A modified parametrization of flux-profile relationships in the surface layer unsing different roughness length values for heat and momentum, Bound.Lay. Meteorol., 72, 331-344, 1995.

Masson, V.: A physically-based scheme for the urban energy budget in atmospheric models, Bound.-Lay. Meteorol., 94, 357-397, 2000.

Masson, V.: Urban surface modeling and the meso-scale impact of cities, Theor. Appl. Climatol, 84, 35-45, 2006.

Masson, V. and Seity, Y.: Including Atmospheric Layers in Vegetation and Urban Offline Surface Schemes, J. Appl. Meteorol. Clim., 48, 1377-1397, 2009.

Masson, V., Grimmond, C. S. B., and Oke, T. R.: Evaluation of the Town Energy Balance (TEB) scheme with direct measurements from dry districts in two cities, J. Appl. Meteorol., 41, 10111026, 2002.

Masson, V., Champeaux, J.-L., Chauvin, F., Meriguet, C., and Lacaze, R.: A Global Database of Land Surface Parameters at 1-km Resolution in Meteorological and Climate Models, J. Climate, 16, 1261-1282, 2003.

Masson, V., Gomes, L., Pigeon, G., Liousse, C., Pont, V., Lagouarde, J.-P., Voogt, J., Salmond, J., Oke, T. R., Hidalgo, J., Legain, D., Garrouste, O., Lac, C., Connan, O., Briottet, X., Lachérade, S., and Tulet, P.: The Canopy and Aerosol Particles
Interactions in TOulouse Urban Layer (CAPITOUL) experiment, Meteorol. Atmos. Phys., 102, 135-157, 2008.

Masson V., Lion, Y., Peter, A., Pigeon, G., Buyck, J., and Brun, E.: "Grand Paris": Regional landscape change to adapt city to climate warming, Climatic Change, 117, 769-782, doi:10.1007/s10584-012-0579-1, 2013.

Milly, P.: A mass-conservative procedure for time-stepping in models of unsaturated flow, Adv. Water Resour., 8, 32-36, 1985.

Mironov, D., Heise, E., Kourzeneva, E., Ritter, B., Schneider, N., and Terzhevik, A.: Implementation of the lake parameterization scheme FLake into the numerical weather prediction model COSMO, Boreal Environ. Res., 15, 218-230, 2010.

Mitchell, K. E., Lohmann, D., Houser, P. R., Wood, E. F., Schaake, J. C., Robock, A., Cosgrove, B. A., Sheffield, J., Duan, Q., Luo, L., Higgins, R. W., Pinker, R. T., Tarpley, J. D., Lettenmaier, D. P., Marshall, C. H., Entin, J. K., Pan, M., Shi, W., Koren, V., Meng, J., Ramsay, B. H., and Bailey, A. A.: The multi-institution North American Land Data Assimilation System (NLDAS): Utilizing multiple GCIP products and partners in a continental distributed hydrological modeling system, J. Geophys. Res., 109, D07S90, doi:10.1029/2003JD003823, 2004.

Mokhtari, M., Gomes, L., Tulet, P., and Rezoug, T.: Importance of the surface size distribution of erodible material: an improvement on the Dust Entrainment And Deposition (DEAD) Model, Geosci. Model Dev., 5, 581-598, doi:10.5194/gmd-5-581-2012, 2012.

Monahan, E., Spiel, D., and Spiel, K.: Oceanic Whitecaps, Reidel, 1986.

Nachtergaele, F., van Velthuizen, H., Verelst, L., and Wiberg, D.: Harmonized World Soil Database, Version 1.2, FAO, IIASA, ISRIC, ISSCAS, JRC, available at: http://www.iiasa. ac.at/Research/LUC/External-World-soil-database/HTML/ (last access: 15 November 2012), 2012.

Noilhan, J. and Lacarrère, P.: GCM Grid-Scale Evaporation from Mesoscale Modeling, J. Climate, 8, 206-223, 1995.

Noilhan, J. and Mahfouf, J. F.: The ISBA land surface parameterization scheme, Global Planet. Change, 13, 145-159, 1996.

Noilhan, J. and Planton, S.: A Simple Parameterization of Land Surface Processes for Meteorological Models, Mon. Weather Rev., 117, 536-549, 1989.

Noilhan, J., Lacarrère, P., Dolman, A. J., and Blyth, E. M.: Defining area-average parameters in meteorological models for land surfaces with mesoscale heterogeneity, J. Hydrol., 190, 302-316, 1997.

Noilhan, J., Donier, S., Lacarrère, P., Sarrat, C., and Le Moigne, P.: Regional-scale evaluation of a land surface scheme from atmospheric boundary layer observations, J. Geophys. Res.-Atmos., 116, D01104, doi:10.1029/2010JD014671, 2011.

Offerle, B., Jonsson, P., Eliasson, I., and Grimmond, C. S. B.: Urban Modification of the Surface Energy Balance in the West African Sahel: Ouagadougou, Burkina Faso, J. Climate, 18, 3983-3995, 2005a.

Offerle, B., Grimmond, C. S. B., and Fortuniak, K.: Heat storage and anthropogenic heat flux in relation to the energy balance of a central European city centre, Int. J. Climatol., 25, 1405-1419, 2005b.

Oki, T. and Sud, Y. C.: Design of Total Runoff Integrating Pathways (TRIP) - A Global River Channel Network, Earth Interact., 2, 137, 1998. 
Parton, W. J., Schimel, D. S., Cole, C. V., and Ojima, D. S.: Analysis of factors controlling soil organic matter levels in Great Plains grasslands, Soil Sci. Soc. Am. J., 51, 1173-1179, 1987.

Pedinotti, V., Boone, A., Decharme, B., Crétaux, J. F., Mognard, N., Panthou, G., Papa, F., and Tanimoun, B. A.: Evaluation of the ISBA-TRIP continental hydrologic system over the Niger basin using in situ and satellite derived datasets, Hydrol. Earth Syst. Sci., 16, 1745-1773, doi:10.5194/hess-16-1745-2012, 2012.

Peeters, F., Livingstone, D. M., Goudsmit, G.-H., Kipfer, R., and Forster, R.: Modeling 50 Years of Historical Temperature Profiles in a Large Central European Lake, Limnol. Oceanogr., 47, 186197, 2002.

Pellarin, T., Delrieu, G., Saulnier, G.-M., Andrieu, H., Vignal, B., and Creutin, J.-D.: Hydrologic Visibility of Weather Radar Systems Operating in Mountainous Regions: Case Study for the Ardèche Catchment (France), J. Hydrometeorol., 3, 539-555, 2002.

Perroud, M., Goyette, S., Martynov, A., Beniston, M., and Anneville, O.: Simulation of multiannual thermal profiles in deep Lake Geneva: A comparison of one-dimensional lake models, Limnol. Oceanogr., 54, 1574-1594, 2009.

Peters-Lidard, C. D., Zion, M. S., and Wood, E. F.: A soilvegetation-atmosphere transfer scheme for modeling spatially variable water and energy balance processes, J. Geophys. Res., 102, 4303-4324, 1997.

Peters-Lidard, C. D., Blackburn, E., Liang, X., and Wood, E. F.: The Effect of Soil Thermal Conductivity Parameterization on Surface Energy Fluxes and Temperatures, J. Atmos. Sci., 55, 1209-1224, 1998.

Petersen, R.: A wind tunnel evaluation of methods for estimating surface roughness length at industrial facilities, Atmos. Environ., 31, 45-57, 1997.

Pigeon, G., Moscicki, M. A., Voogt, J. A., and Masson, V.: Simulation of fall and winter surface energy balance over a dense urban area using the TEB scheme, Meteorol. Atmos. Phys., 102, 159-171, 2008

Porson, A., Harman, I., Bohnenstengel, S., and Belcher, S.: How Many Facets are Needed to Represent the Surface Energy Balance of an Urban Area?, Bound.-Lay. Meteorol., 132, 107-128, 2009.

Queguiner, S., Martin, E., Lafont, S., Calvet, J.-C., Faroux, S., and Quintana-Seguí, P.: Impact of the use of a $\mathrm{CO}_{2}$ responsive land surface model in simulating the effect of climate change on the hydrology of French Mediterranean basins, Nat. Hazards Earth Syst. Sci., 11, 2803-2816, doi:10.5194/nhess-11-28032011, 2011.

Quintana Seguí, P., Le Moigne, P., Durand, Y., Martin, E., Habets, F., Baillon, M., Canellas, C., Franchisteguy, L., and Morel, S.: Analysis of Near-Surface Atmospheric Variables: Validation of the SAFRAN Analysis over France, J. Appl. Meteorol. Clim., 47, 92-107, 2008.

Quintana Seguí, P., Martin, E., Habets, F., and Noilhan, J.: Improvement, calibration and validation of a distributed hydrological model over France, Hydrol. Earth Syst. Sci., 13, 163-181, doi:10.5194/hess-13-163-2009, 2009.

Redler, R., Valcke, S., and Ritzdorf, H.: OASIS4 - a coupling software for next generation earth system modelling, Geosci. Model Dev., 3, 87-104, doi:10.5194/gmd-3-87-2010, 2010.
Reichle, R. H. and Koster, R. D.: Bias reduction in short records of satellite soil moisture, Geophys. Res. Lett., 31, L19501, doi:10.1029/2004GL020938, 2004.

Reichle, R. H., Koster, R. D., Liu, P., Mahanama, S. P. P., Njoku, E. G. and Owe, M.: Comparison and assimilation of global soil moisture retrievals from the Advanced Microwave Scanning Radiometer for the Earth Observing System (AMSR-E) and the Scanning Multichannel Microwave Radiometer (SMMR), J. Geophys. Res., 112, D09108, doi:10.1029/2006JD008033, 2007.

Rodell, M., Houser, P. R., Jambor, U., Gottschalck, J., Mitchell, K., Meng, C.-J., Arsenault, K., Cosgrove, B., Radakovich, J., Bosilovich, M., Entin, J. K., Walker, J. P., Lohmann, D., and Toll, D.: The Global Land Data Assimilation System, Bull. Amer. Meteor. Soc., 85, 381-394, 2004.

Rüdiger, C., Albergel, C., Mahfouf, J.-F., Calvet, J.-C. and Walker, J. P.: Evaluation of the observation operator Jacobian for leaf area index data assimilation with an extended Kalman filter, J. Geophys. Res., 115, D09111, doi:10.1029/2009JD012912, 2010.

Rutter, N., Essery, R., Pomeroy, J., Altimir, N., Andreadis, K., Baker, I., Barr, A., Bartlett, P., Boone, A., Deng, H., Douville, H., Dutra, E., Elder, K., Ellis, C., Feng, X., Gelfan, A., Goodbody, A., Gusev, Y., Gustafsson, D., Hellström, R., Hirabayashi, Y., Hirota, T., Jonas, T., Koren, V., Kuragina, A., Lettenmaier, D., Li, W.-P., Luce, C., Martin, E., Nasonova, O., Pumpanen, J., Pyles, R. D., Samuelsson, P., Sandells, M., Schädler, G., Shmakin, A., Smirnova, T. G., Stähli, M., Stöckli, R., Strasser, U., Su, H., Suzuki, K., Takata, K., Tanaka, K., Thompson, E., Vesala, T., Viterbo, P., Wiltshire, A., Xia, K., Xue, Y. and Yamazaki, T.: Evaluation of forest snow processes models (SnowMIP2), J. Geophys. Res., 114, D06111, doi:10.1029/2008JD011063, 2009.

Sabater, J. M., Rüdiger, C., Calvet, J. C., Fritz, N., Jarlan, L., and Kerr, Y.: Joint assimilation of surface soil moisture and LAI observations into a land surface model, Agr. Forest Meteorol., 148, 1362-1373, 2008.

Salgado, R. and Le Moigne, P.: Coupling the Flake model to the Surfex externalized surface model, Boreal Environ. Res., 15, 231244, 2010.

Santiago, J. and Martilli, A.: A Dynamic Urban Canopy Parameterization for Mesoscale Models Based on Computational Fluid Dynamics Reynolds-Averaged Navier-Stokes Microscale Simulations, Bound.-Lay. Meteorol., 137, 417-439, 2010.

Schulz, M., de Leeuw, G., and Balkanski, Y. Sea-salt aerosol source functions and emissions, in: Emission of Atmospheric Trace Compounds, edited by: Granier, C., Artaxo, P., and Reeves, C. E., Kluwer Academic Publishers, 333-359, 2004.

Seinfeld, J. H. and Pandis, S. N.: Atmospheric Chemistry and Physics: Air Pollution to Climate, Wiley, 1997.

Seity, Y., Brousseau, P., Malardel, S., Hello, G., Benard, P., Bouttier, F., Lac, C., and Masson, V.: The AROME-France ConvectiveScale Operational Model, Mon. Weather Rev., 139, 976-991, 2011.

Shao, Y., Raupach, M. R., and Findlater, P. A.: Effect of Saltation Bombardment on the Entrainment of Dust by Wind, J. Geophys. Res., 98, 12719-12726, 1993.

Silvapalan, M., Beven, K., and Wood, E.: On hydrologic similarity: 2. A scaled model of storm runoff production, Water Resour. Res., 23, 2266-2278, 1987. 
Slater, A. G., Pitman, A. J., and Desborough, C. E.: The validation of a snow parameterization designed for use in general circulation models, Int. J. Climatol., 18, 595-617, 1998.

Slater, A. G., Schlosser, C. A., Desborough, C. E., Pitman, A. J., Henderson-Sellers, A., Robock, A., Vinnikov, K. Y., Mitchell, K., Boone, A., Braden, H., Chen, F., Cox, P. M., de Rosnay, P., Dickinson, R. E., Dai, Y. J., Duan, Q., Entin, J., Etchevers, P., Gedney, N., Gusev, Y. M., Habets, F., Kim, J., Koren, V., Kowalczyk, E. A., Nasonova, O. N., Noilhan, J., Schaake, S., Shmakin, A. B., Smirnova, T. G., Verseghy, D., Wetzel, P., Yue, X., Yang, Z. L., and Zeng, Q.: The representation of snow in land surface schemes: Results from PILPS 2(d), J. Hydrometeorol., 2, 7-25, 2001

Smith W. H. F. and Sandwell, D. : Global seafloor topography from satellite altimetry and ship depth soundings, Science, 277, 19561962, 1997.

Solmon, F., Sarrat, C., Serça, D., Tulet, P., and Rosset, R.: Isoprene and monoterpenes biogenic emissions in France: modeling and impact during a regional pollution episode, Atmos. Environ., 38, 3853-3865, 2004.

Spans, E. J. A. and Baker, J. M.: The soil moisture characteristic: Its measurement and similarity to the soil moisture characteristic, Soil Sci. Soc. Am. J., 60, 13-19, 1996.

Stepanenko, V. M. and Lykosov, V. N.: Numerical modelling of heat and moisture transfer processes in the system "water reservoir soil”, Russ. Meteorol. Hydrol., 3, 95-104, 2005.

Stepanenko, V. M., Goyette, S., Martynov, A., Perroud, M., Fang, X., and Mironov, D.: First steps of a Lake Model Intercomparison Project: LakeMIP, Boreal Env. Res., 15, 191-202, 2010.

Subin, Z., Riley, W., and Mironov, D.: An improved lake model for climate simulations: Model structure, evaluation and sensitivity analyses in CESM1, J. Adv. Model. Earth Syst., 4, M02001, doi:10.1029/2011MS000072, 2012.

Taylor, J. P., Edwards, J. M., Glew, M. D., Hignett, P., and Slingo, A.: Studies with a flexible new radiation code. II: Comparisons with aircraft short-wave observations, Q. J. R. Meteorol. Soc., 122, 839-861, 1996.

Thirel, G., Martin, E., Mahfouf, J.-F., Massart, S., Ricci, S., Regimbeau, F., and Habets, F.: A past discharge assimilation system for ensemble streamflow forecasts over France - Part 2: Impact on the ensemble streamflow forecasts, Hydrol. Earth Syst. Sci., 14, 1639-1653, doi:10.5194/hess-14-1639-2010, 2010.

Tulet, P., Crassier, V., Solmon, F., Guedalia, D., and Rosset, R.: Description of the Mesoscale Nonhydrostatic Chemistry model and application to a transboundary pollution episode between northern France and southern England, J. Geophys. Res., 108, 4021, doi:10.1029/2000JD000301, 2003.

Tulet, P., Crassier, V., Cousin, F., Suhre, K., and Rosset, R.: ORILAM, a three-moment lognormal aerosol scheme for mesoscale atmospheric model: Online coupling into the MesoNH-C model and validation on the Escompte campaign, J. Geophys. Res., 110, D18201, doi:10.1029/2004JD005716, 2005.

Vergnes, J.-P. and Decharme, B.: A simple groundwater scheme in the TRIP river routing model: global off-line evaluation against GRACE terrestrial water storage estimates and observed river discharges, Hydrol. Earth Syst. Sci., 16, 3889-3908, doi:10.5194/hess-16-3889-2012, 2012.

Vergnes, J.-P., Decharme, B., Alkama, R., Martin, E., Habets, F., and Douville, H.: A Simple Groundwater Scheme for Hy- drological and Climate Applications: Description and Off-line Evaluation over France, J. Hydrometeorol., 13, 1149-1171, doi10.1175/JHM-D-11-0149.1, 2012.

Verseghy, D. L.: CLASS: A Canadian land surface scheme for GCMS. I. Soil model, Int. J. Climatol, 11, 111-133, 1991.

Vignati, E., de Leeuw, G., and Berkowicz, R.: Modeling coastal aerosol transport and effects of surf-produced aerosols on processes in the marine atmospheric boundary layer, J. Geophys. Res., 106, 20225-20238, 2001.

Vincendon, B., Ducrocq, V., Saulnier, G. M., Bouilloud, L., Chancibault, K., Habets, F., and Noilhan, J.: Benefit of coupling the ISBA land surface model with a TOPMODEL hydrological model version dedicated to Mediterranean flash-floods, J. Hydrol., 394, 256-266, 2010.

Vionnet, V., Brun, E., Morin, S., Boone, A., Faroux, S., Le Moigne, P., Martin, E., and Willemet, J.-M.: The detailed snowpack scheme Crocus and its implementation in SURFEX v7.2, Geosci. Model Dev., 5, 773-791, doi:10.5194/gmd-5-773-2012, 2012

Viterbo, P. and Courtier, P.: The importance of soil water for medium rangeweather forecasting. Implications for data assimilation, Workshop on Imbalance of Slowly Varying Components of Predictable Atmospheric Motions, Beijing, China, World Meteor. Org., 121-130, 1995.

Voldoire, A., Sanchez-Gomez, E., Salas y Mélia, D., Decharme, B., Cassou, C., Sénési, S., Valcke, S., Beau, I., Alias, A., Chevallier, M., Déqué, M., Deshayes, J., Douville, H., Fernandez, E., Madec, G., Maisonnave, E., Moine, M.-P., Planton, S., SaintMartin, D., Szopa, S., Tyteca, S., Alkama, R., Belamari, S., Braun, A., Coquart, L., and Chauvin, F.: The CNRM-CM5.1 global climate model: description and basic evaluation, Clim. Dynam., 1-31, 2012.

Wade, M., Caniaux, G., DuPenhoat, Y., Dengler, M., Giordani, H., and Hummels, R.: A one-dimensional modeling study of the diurnal cycle in the equatorial Atlantic at the PIRATA buoys during the EGEE-3 campaign, Ocean Dynam., 61, 1-20, 2011.

Weill, A., Eymard, L., Caniaux, G., Hauser, D., Planton, S., Dupuis, H., Brut, A., Guerin, C., Nacass, P., Butet, A., Cloché, S., Pedreros, R., Durand, P., Bourras, D., Giordani, H., Lachaud, G., and Bouhours, G.: Toward a Better Determination of Turbulent Air-Sea Fluxes from Several Experiments, J. Climate, 16, 600618, 2003.

Wesely, M.: Parametrizations of surface resistance to gaseous dry deposition in regional scale, numerical models, Atmos. Environ. 23, 1293-1304, 1989.

Wesely, M. L. and Hicks, B. B.: Some factors that affect the deposition rates of sulfur dioxide and similar gases on vegetation, JAPCA J. Air Waste Ma., 27, 1110-1116, 1977.

Wetzel, P. J. and Chang, J.-T.: Concerning the Relationship between Evapotranspiration and Soil Moisture, J. Clim. Appl. Meteorol., 26, 18-27, 1987.

Wieringa, J.: Representative roughness parameters for homogeneous terrain, Bound.-Lay. Meteorol., 63, 323-363, 1993.

Wood, E. F., Lettenmaier, D. P., and Zartarian, V. G.: A LandSurface Hydrology Parameterization With Subgrid Variability for General Circulation Models, J. Geophys. Res., 97, 27172728, 1992.

Wood, E. F., Lettenmaier, D. P., Liang, X., Lohmann, D., Boone, A., Chang, S., Chen, F., Dai, Y. J., Dickinson, R. E., Duan, Q. Y., Ek, M., Gusev, Y. M., Habets, F., Irannejad, P., Koster, R., Mitchel, K. 
E., Nasonova, O. N., Noilhan, J., Schaake, J., Schlosser, A., Shao, Y. P., Shmakin, A. B., Verseghy, D., Warrach, K., Wetzel, P., Xue, Y. K., Yang, Z. L., and Zeng, Q. C.: The Project for Intercomparison of Land-surface Parameterization Schemes (PILPS) phase 2(c) Red-Arkansas River basin experiment: 1. Experiment description and summary intercomparisons, Global Planet. Change, 19, 115-135, 1998.

Wood, N. and Mason, P.: The Pressure force induced by neutral, turbulent flow over hills, Q. J. R. Meteorol. Soc., 119, 12331267, 1993.

Yang, Z.-L., Dickinson, R. E., Robock, A., and Vinnikov, K. Y.: Validation of the Snow Submodel of the Biosphere-Atmosphere Transfer Scheme with Russian Snow Cover and Meteorological Observational Data, J. Climate, 10, 353-373, 1997.
Zender, C., Bian, H., and Newman, D.: The mineral dust entrainment and deposition (dead) model: Description and global dust distribution, J. Geophys. Res., 108, 4416, doi:10.1029/2002JD002775, 2003.

Zender, C. S., Miller, R. L., and Tegen, I.: Quantifying mineral dust mass budgets: Terminology, constraints, and current estimates, EOS T. Am. Geophys. Un., 85, 509-512, 2004.

Zhao, R. J.: The Xinanjiang model applied in China, J. Hydrol., 134, 317-381, 1992. 